

\section{DISCLAIMER}

This report was prepared as an account of work sponsored by an agency of the United States Government. Neither the United States Government nor any agency Thereof, nor any of their employees, makes any warranty, express or implied, or assumes any legal liability or responsibility for the accuracy, completeness, or usefulness of any information, apparatus, product, or process disclosed, or represents that its use would not infringe privately owned rights. Reference herein to any specific commercial product, process, or service by trade name, trademark, manufacturer, or otherwise does not necessarily constitute or imply its endorsement, recommendation, or favoring by the United States Government or any agency thereof. The views and opinions of authors expressed herein do not necessarily state or reflect those of the United States Government or any agency thereof. 


\section{DISCLAIMER}

Portions of this document may be illegible in electronic image products. Images are produced from the best available original document. 


\title{
LEEAT NOTICE
}

This report was prepared as an account of work sponsored by the United States Government. Neither the United States nor the United States Atomic Energy Commission, nor any of their employees, nor any of their contractors, subcontractors, or their employees, makes any warranty, express or implied, or assumes any legal liability or responsibility for the accuracy, completeness or usefulness of any information, apparatus, product or process disclosed, or represents that its use would not infringe privately owned rights.

\section{HANFORD ENGINEERING DEVELOPMENT LABORATORY}

\author{
Richland, Washington \\ operated by

\section{WADCO CORPORATION}

A Subsidiary of Westinghouse Electric Corporation

for the

United States Atomic Energy Commission Under Contract No. AT(45-I)-2I70 
WHAN-FR-32

UC-10, Special

Distribution

\section{RECEIVED CY DTIE FEB I \$97! \\ APPLICATION OF AQUEOUS TECHNOLOGY TO LMFBR \\ SEPARATIONS PROCESSES. PROGRAM PLAN FOR}

TASK T-1: SOLVENT PERFORMANCE

\section{THIS DOCUMENT CONFIRMED AS UNCLASSIFIED DIVISION OF CLASSIFICATION

BATE $\frac{\text { lack H)cahnlamk }}{2122171}$

\section{,}

G. L. Richardsof

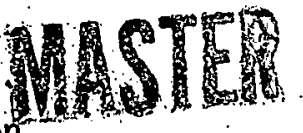

This report was prepared as an account of work sponsored by the United States Government. Neither the United States nor the United States Atomic Energy Commission, nor any of their employees, nor any of their contractors, subcontractors, or their employees, makes any warranty, express or implied, or assumes any legal liability or responsibility for the accuracy, completeness or usefulness of any information, apparatus, product or process disclosed, or represents that its use would not infringe privately owned rights.

December, 1970

FIRST UNRESTRIGTED

DISTRIBUTION MADE

JAN 1991

UNCLASSIFIED 
Printed in the United States of America Available from

National Technical Information Service National Bureau of Standards, U.S. Department of Commerce Springfield, Virginia 22151

Price: Printed Copy $\$ 3.00$; Microfiche $\$ 0.65$ 


\section{CONTENTS}

\section{Page}

INTRODUCTION . . . . . . . . . . . . . . . . . 1

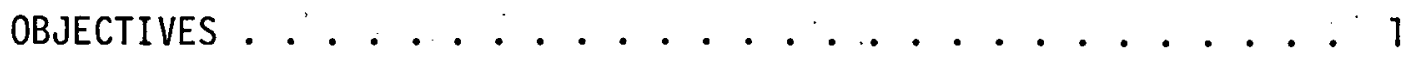

DESCRIPTION OF WORK ....................... 2

EQUIPMENT ....................... 4

FEED MATERIALS AND FLOWSHEETS . . . . . . . . . . . 13

OPERATING PROCEDURES ........................ 17

DOSIMETRY MEASUREMENTS AND CALCULATIONS $\ldots \ldots . . . . . . . .21$

TENTATIVE RUN SCHEDULE . . . . . . . . . . . . . . . 24

PERFORMANCE CRITERIA . . . . . . . . . . . . . . . . 25

REFERENCES ...................... 37

APPENDIX A - CALCULATION OF ACCUMULATED SOLVENT DOSE

APPENDIX B - CALCULATION OF SINGLE-PASS SOLVENT DOSE

APPENDIX C - ESTIMATION OF BETA AND GAMMA ENERGY ABSORPTION IN IRRADIATION VESSELS

APPENDIX D - URANIUM, PLUTONIUM AND FISSION PRODUCT ANALYTICAL METHODS 
APPLICATION OF AQUEOUS TECHNOLOGY TO LMFBR SEPARATIONS PROCESSES.

PROGRAM PLAN FOR TASK T-1: SOLVENT PERFORMANCE

\author{
G. L. Richardson
}

INTRODUCTION

The Purex process is currently the prime candidate for reprocessing LMFBR fuels. These fuels will be irradiated to very high burnups $(100,000$ MWd/MT or more) at high specific powers (1000 to $2000 \mathrm{~kW} / \mathrm{kg}$ of fissile plutonium); consequently, the solvent radiation exposure will be many-fold higher than in current reprocessing plants, particularly if cooling times as short as 30 days are used to reduce the plutonium inventory.

Over the last 15 years or so, a tremendous amount of 1aboratory work has been performed world-wide to determine the effects of irradiation on TBP (tributyl phosphate) and various diluents. $(1,12)$ such work, typically, has involved external irradiation of extractants (either alone or in contact with some aqueous phase) to a particular desired dose. Subsequent anatyses and empirical solvent quality tests have been used to estimate solvent performance as a function of absorbed dose. Results of these tests have generally been quite encouraging and, as far as they go, indicate that TBP should be a suitable extractant for processing of LMFBR fuels.

Nevertheless, a system undergoing continuous irradiation at levels expected from processing LMFBR fuels may exhibit kinetic, emulsifying, and other inherent effects which could seriously impair the performance of a TBP extractant even in a single cycle of extraction. Furthermore, conventional solvent washing procedures may be inadequate to prevent accumulation of deleterious degradation products of TBP and diluent in the recycled solvent. Answers to these and similar questions about the performance of a TBP extractant in processing LMFBR fuels can best be provided by an evaluation of solvent performance under dynamic conditions. The purpose of this experimental task is to conduct such a study.

\title{
OBJECTIVES
}

Laboratory-scale investigation of TBP solvent performance will be conducted with the following objectives:

1. Determine TBP solvent performance using a dynamic system with radioactive feed solutions as near to those expected from LMFBR as 
practicable. Specifically, the dynamic system will be operated to establish and evaluate the effects of irradiation dose rate and cumulative exposure on TBP solvent properties as they relate to process kinetics, plutonium and uranium losses in the $1 B$ and $1 C$ column stripping operations, and fission product decontamination in the product streams.

2. Note and resolve differences, if any, between solvent performance data established in the dynamic tests and either the data from present laboratory tests or actual solvent quality data from the Hanford Purex Plant.

3. Provide a reliable means of extrapolating solvent performance in the dynamic system to plant-scale performance in any of several kinds of contactors.

4. Determine the effectiveness of conventional solvent washing treatments in maintaining and restoring the quality of TBP solvent used to process LMFBR fuels and, if necessary, develop and test suitable washing procedures.

In fulfilling these objectives, we expect to maintain close liaison with ORNL personnel who are conducting similar studies on a batch basis.

\section{DESCRIPTION OF WORK}

The experimental apparatus will consist of a single-stage mixer for the irradiation (1A) contact, a miniature continuous centrifuge for rapid separation of the phases leaving the mixing stage, and three multi-stage banks of Savannah River Laboratory-type miniature centrifugal contactors in series performing the functions of a $1 \mathrm{~A}$ column scrub section, a $1 \mathrm{~B}$ column extraction section, and a $1 C$ column. One or more single-stage mixers will be used to continuously wash the spent solvent for immediate recycle for those tests involving cumulative radiation dose effects. The system will be operated to demonstrate the performance of a Purex process first extraction cycle at varying solvent phase residence times and radiation exposure rates. The studies will be conducted in C-Cell of the WADCO $325 \mathrm{~A}$ Building.

For such studies multi-stage, miniature centrifugal contactors are a convenient research tool. They have several desirable characteristics as 
compared to other laboratory-scale contactors: steady state conditions are attained rapidly. upon start-up because of the low holdup volumes per stage, high throughput rates minimize experimental running times, and, of special advantage, phase residence times per stage can be easily varied to correspond to contactors with both short and long (e.g., pulse column) residence times.

In the scheduled test runs, the feed solutions to the $I A$ and $I A$ scrub contactors will simulate, as far as possible, the chemical and radiochemical composition expected for actual LMFBR feed solutions. Such feed solutions will be prepared from irradiated fuel dissolver solution and a rare earth (Ce-144) concentrate prepared by the Hanford Waste Management Program. Local sources of plutonium, uranium, etc., will be used as required. The extractant for the runs will be a solution of TBP in a normal paraffin hydrocarbon diluent (primarily n-dodecane). Appropriate scrub, partition, and strip solutions will be introduced at the proper points in the system. The extractant will be washed after each pass through the system by contact with an appropriate wash (initially a $\mathrm{Na}_{2} \mathrm{CO}_{3}$ solution) and, for the recycle tests, returned to the extraction contactor. For each set of flowsheet conditions, appropriate end-stream samples will be taken from each of the contactors to establish how loss and decontamination patterns change with solvent exposure rate and cumulative dose.

A series of runs will also be made under Hanford Purex Plant flowsheet conditions to establish the reliability of extrapolating the results of the Taboratory tests to full-scale plant conditions. The range of operating conditions and dose rates will extend and complement the results obtained with the LMFBR feed solutions.

For each set of operating conditions, portions of the extractant will be removed from the system periodically, tested, and analyzed to evaluate solvent behavior further. Various standard solvent quality tests (e.g. distribution ratio measurements, dispersion-disengaging behavior, plutonium retention, physical properties) will be made. Such tests are sensitive indicators of changes in the chemical and physical behavior of TBP extractants; and, based on Hanford Purex Plant experience, they can be useful indices of the expected performance of a solvent during plant operation.

Knowledge of the rate at which the solvent receives irradiation in the various parts of the dynamic system is an essential prerequisite to 
obtaining credible and usable data about actual and expected solvent stability and performance. Two approaches will be used to obtain reliable estimates of dose rates. One will involve calculation of dose rates using known contactor geometry, aqueous and organic phase compositions, etc. The other will involve the use of TBP as a dosimeter. G values for the formation of DBP (dibutyl phosphate) from TBP are well known, $(2,12)$ and refined analytical techniques for DBP have been recently developed. $(3,4,12,13)$ During initial dosimeter tests, it is planned to operate the system with radioactively simulated LMFBR feeds which do not contain uranium, plutonium, or other cations strongly complexed by DBP in order to simplify DBP analyses.

Results obtained in FY 1970 include the fabrication and shakedown testing of the experimental apparatus, comparison of different methods for determining DBP concentrations, and preliminary evaluation of the proposed dose rate calculation, methods. The bulk of the high-level testing will he performed in FY 1971 with the completion of the tests with Purex and dilute LMFBR flowsheets expected. Work with more advanced flowsheets will be completed in FY. 1972. Reports summarizing the experimental results will be prepared at the conclusion of specific flowsheet studies.

\section{EQUIPMENT}

A simplified layout of the experimental apparatus is shown in Figure 1 . It consists of the following equipment arranged in series:

- Feed preparation tanks where stock solutions of uranium, plutonium, fission product concentrates, and "cold" chemicals are blended.

- In-cell feed tanks for recycled solvent (IAX) and radioactive feeds (Ce-144 irradiation solution and IAF).

- A single-stage $1 A$ irradiation contactor overflowing to a miniature centrifuge.

- An 8-stage bank of modified Savannah River Laboratory (SRL)-type centrifugal contactors serving as a $1 \mathrm{~A}$ column for introduction of the full fission product spectrum and to demonstrate fission product scrubbing performance of the irradiated solvent leaving the $1 \mathrm{~A}$ contactor.

- A 6-stage bank of centrifugal contactors serving as a 1BX column to demonstrate plutonium and fission product partitioning. 


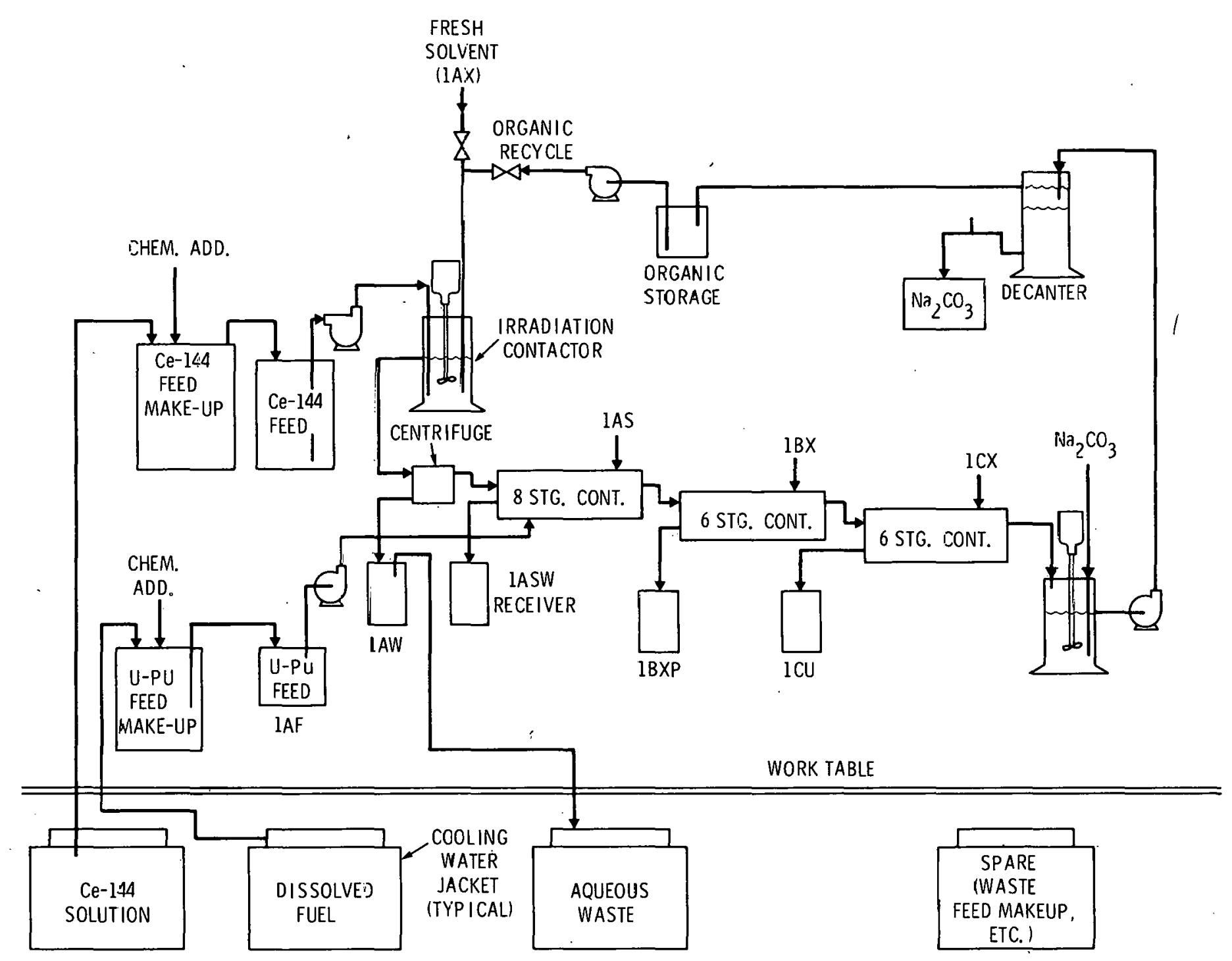

G

FIGURE 1. SCHEMATIC. LMFBR SOLVENT EXTRACTION TEST STAND, C-CELL, 325 BLDG. 
- A 6-stage bank of centrifugal contactors serving as a IC column to demonstrate uranium stripping behavior and retention of uranium, plutonium, and fission products in the stripped solvent.

- A solvent washing facility consisting of a single stage mixer for washing the solvent with dilute sodium carbonate, a solvent decanter for phase separation, and a solvent storage vessel from which the washed solvent can be recycled to the irradiation ( $1 A$ ) contactor. Additional scrubbing vessels will be added if necessary to restore solvent quality.

The equipment will be installed on a stainless-steel table top in C-Cell of the 325A Building Hot Cell facility. Several large tanks are located below the work table for storage of the fission product stock solutions and for interim storage of high-level waste solutions. Solutions will be transferred between tanks by. pressurization and/or vacuum transfer techniques. Feed, scrub, and strip solutions will be pumped to the test apparatus by positive displacement metering pumps (FMI Lab Pumps, Fluid Metering, Inc.). Further details of the contactors and the reason for their selection are described in the following sections.

\section{Single-Stage Mixers}

The single-stage contactors to be used for the irradiation contact and for solvent washing are made from the bottom sections of graduated glass cylinders. Vigorous agitation is supplied by 4-bladed stirrers turned by laboratory motors at about $2400 \mathrm{rpm}$. Baffles are installed in the larger vessels to minimize vortex formation and to assure complete, homogeneous mixing. The operating volume of each mixer is set by an overflow tube installed at the desired operating leve1. Currently we have 5 of these contactors built with overflows at $34,59,115,160$ and $320 \mathrm{ml}$, respectively; actual operating volumes will be slightly less than these because of the volume occupied by the agitator and by the vortex developed by the agitator. The three smaller vessels (nominally 30,50 and $100 \mathrm{ml}$ ) were sized to provide extraction contact solvent residence times of 4 to $12 \mathrm{~min}$., comparable to the residence time obtained in pulse columns, as discussed in Appendix B. Aqueous and organic feeds will be introduced near the bottom of the vessel to minimize short-circuiting of the feed to the overflow. The contactors 
to be used in the cell are jacketed for hot water heating.

Confirmation that homogeneous mixing and a constant phase volume ratio will be attained in the contactors was obtained in special tests with a $30 \mathrm{ml}$ mixing vessel. The solvent and aqueous feed streams were introduced to the initially-empty contactor at a constant rate. Periodic samples of the overflowing mixture were taken to determine if the flow rates of aqueous and organic phases from the mixer were the same as those into the mixer. At the end of the test, the agitator was shut off and the volume ratio of the two phases left in the mixer was measured. The results, presented in Table $I$, show that the aqueous/organic $(A / O)$ ratio in each of the collected samples and in the solution remaining in the mixer at the end of the test was the same as the ratio of the streams into the mixer within $\pm 4 \%$. Similar performance was observed in $20 \mathrm{~min}$. tests with a $100 \mathrm{ml}$, baffled mixing vesse1. Further confirmation of intimate mixing is shown in Figure 2, a high-speed photograph of dispersion obtained in a $50 \mathrm{ml}$ contactor. The maximum dispersed drop size, scaled from this photograph, was about $0.6 \mathrm{~mm}$.

\section{TABLE I EFFLUENT VOLUME MEASUREMENTS}

Test 1: Nominal A/O Flow Ratio $=1.0$

\begin{tabular}{|c|c|c|c|c|}
\hline \multirow[b]{2}{*}{ Sample } & \multirow{2}{*}{$\begin{array}{c}\text { Time Period } \\
\text { Min }\end{array}$} & \multicolumn{2}{|c|}{ Volume, $\mathrm{ml}$} & \multirow[b]{2}{*}{$\mathrm{A} / 0$} \\
\hline & & Aqueous & Organic & \\
\hline 1 & $5-10$ & 19.8 & 19.0 & 1.042 \\
\hline 2 & $15-20$ & 19.3 & 19.6 & 0.985 \\
\hline 3 & $30-35$ & 19.0 & 19.1 & 0.995 \\
\hline 4 & $60-65$ & 19.6 & 19.8 & 0.990 \\
\hline Total Feed In & $0-65$ & 253 & 253 & 1.000 \\
\hline $\begin{array}{l}\text { Volume Left In } \\
\text { Mixer }\end{array}$ & End & 13 & 13 & 1.000 \\
\hline
\end{tabular}

Test 2: Nominal A/0 Flow Ratio $=0.23$

$\begin{array}{ccccc}1 & 6-11 & 4.6 & 19.4 & 0.237 \\ 2 & 15-20 & 4.4 & 19.45 & 0.226 \\ 3 & 30-35 & 4.4 & 19.4 & 0.227 \\ 4 & 60-65 & 4.6 & 20.0 & 0.230 \\ \text { Total Feed In } & 0-65 & 58 & 253 & 0.229 \\ \begin{array}{l}\text { Volume Left In } \\ \text { Mixer }\end{array} & \text { End } & 4.7 & 20.6 & 0.228\end{array}$




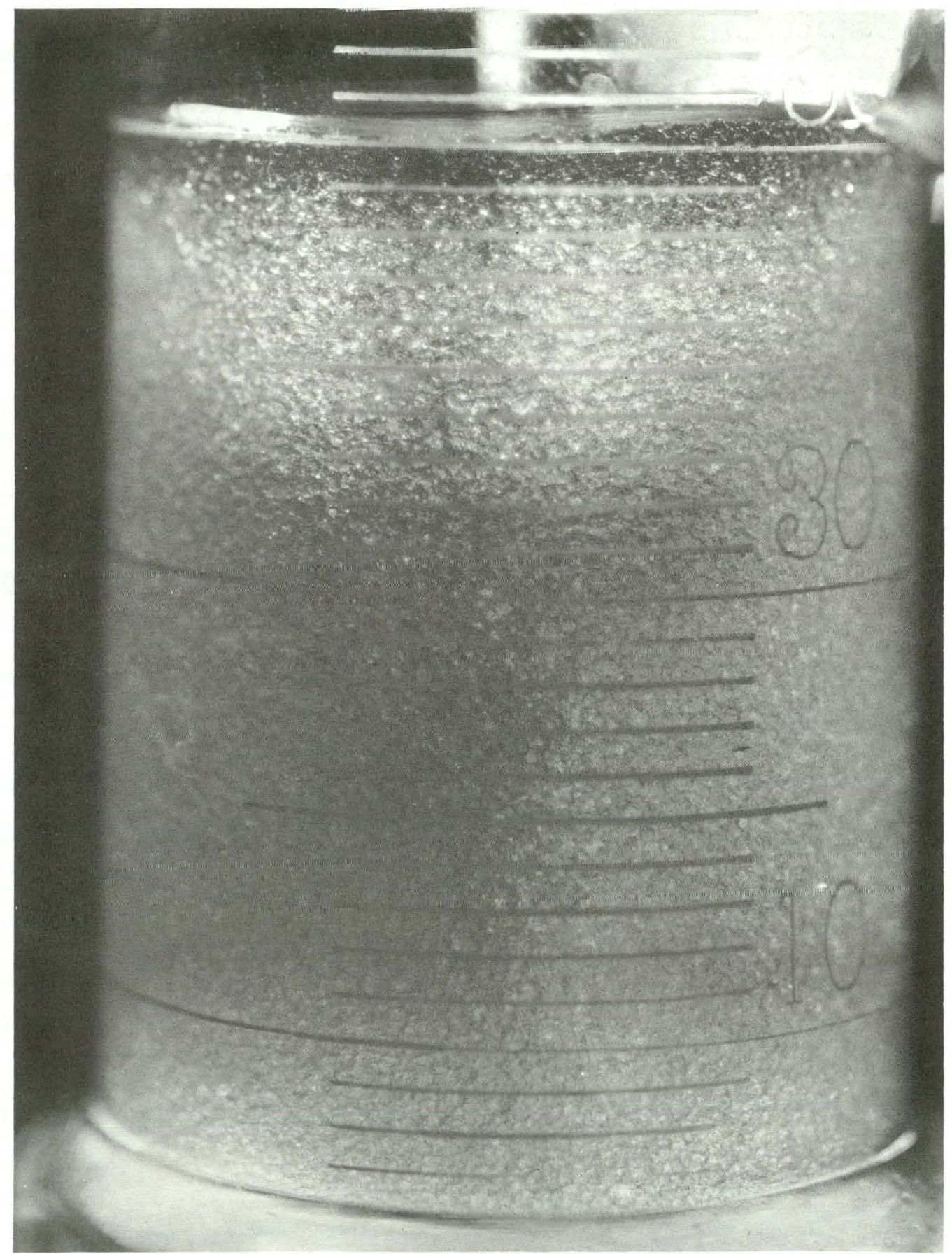

FIGURE 2. CLOSE UP OF UNJACKETED 50 ML MIXING VESSEL SHOWING TYPICAL DISPERSION OBTAINED IN 1 A IRRADIATION CONTACTORS. 
The single stage mixer design was chosen because of its simplicity of construction, operation, and geometry for dose rate calculations. Originally we planned to use a multi-stage contactor for this purpose, but each additional stage would add an uncertainty factor in the dose rate calculations because of the increased geometrical complexity. The only benefit of a multi-stage unit would be the detection of inextractable uranium or plutonium species that might be produced by solvent degradation. However, there is a strong probability that several added stages would still not give representative uranium-plutonium losses because our Ce-144 stock solution is contaminated with phosphoric acid from prior separations plant processing. We do not have a source of phosphate-free feed since all of the available high level fission products are contaminated to some extent by phosphate-based solvents.

\section{Centrifugal Contactors}

Multi-stage miniature centrifugal contactors based on an SRL design $(5,6)$ are used to provide the succeeding $1 A$ contactor scrub section, $\mathrm{IBX}$, and $\mathrm{IC}$ contactor functions; and a single miniature centrifuge of the same design is used to separate the mixed phases overflowing from the $1 \mathrm{~A}$ single-stage mixer. The mixer and centrifuge sections of these contactors are virtually identical with the SRL design, but they are arranged in linear, rectangular blocks containing 6 or 8 compiete stages rather than the 16-stage circular design used at SRL. Electrical strip heaters are mounted on the sides of the blocks to permit operation at elevated temperatures. Figure 3 is a photograph of a disassembled six-stage contactor; Figure 4 shows two of these contactors in series operation, and Figure 5 shows the three multi-stage centrifuge units as they will be installed in the cell.

The SRL stages reportedly have a holdup of $3 \mathrm{ml}$ in the mixing section and $7 \mathrm{ml}$ in the centrifuge section. Our own calculations, based on the SRL drawings, show that holdup volume in the centrifuge bow 1 is about $4.5 \mathrm{~m} 1$ to the overflow weirs. The relative proportions of aqueous and organic phases in each stage depend on the respective flow rates and the ratio of phase densities. The organic holdup in the mixer section is determined primarily by the aqueous/organic flow ratio, while that in the centrifuge 


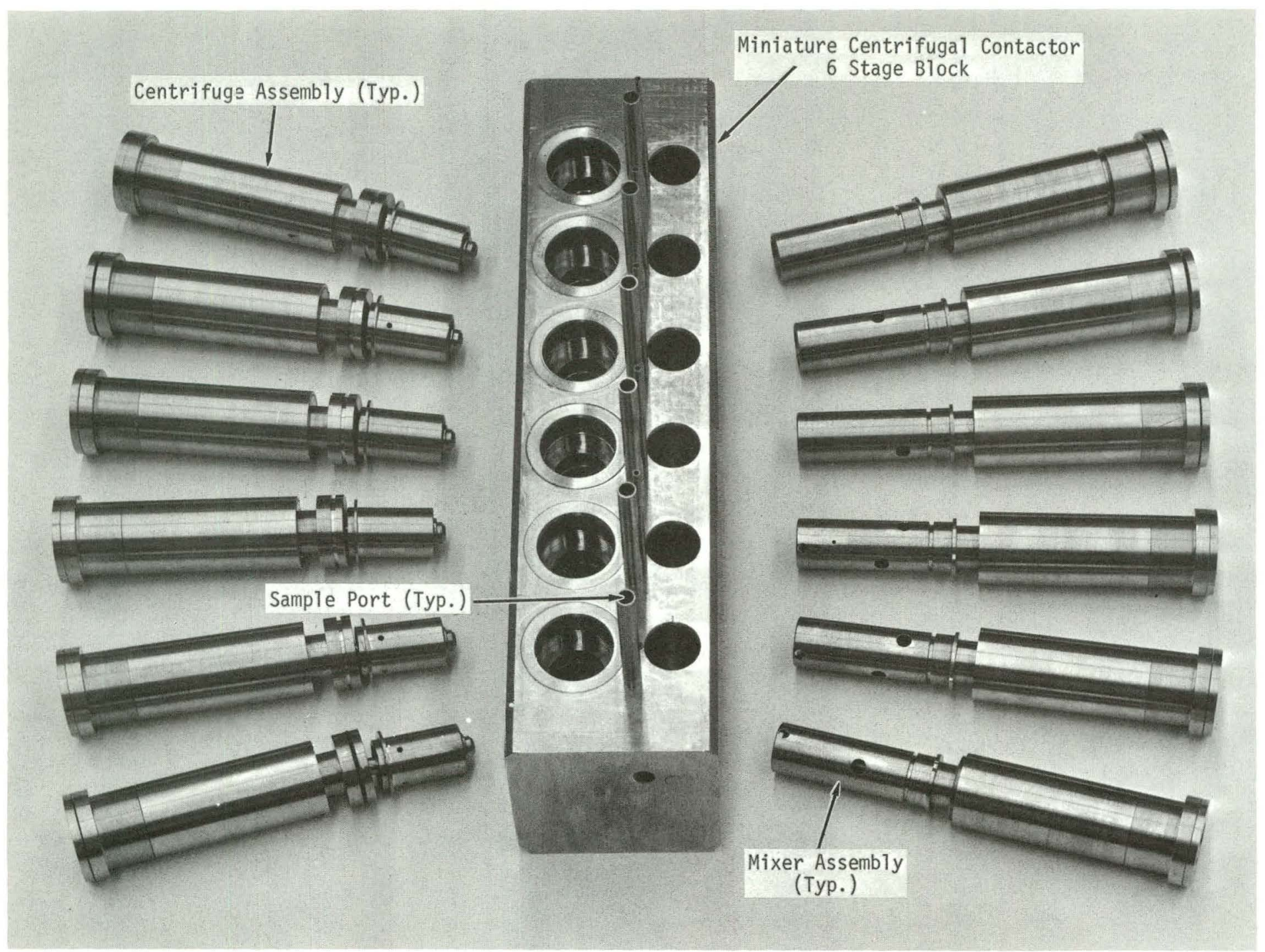

FIGURE 3: EXPLODED VIEW OF 6-STAGE MINIATURE CENTRIFUGAL CONTACTOR. 


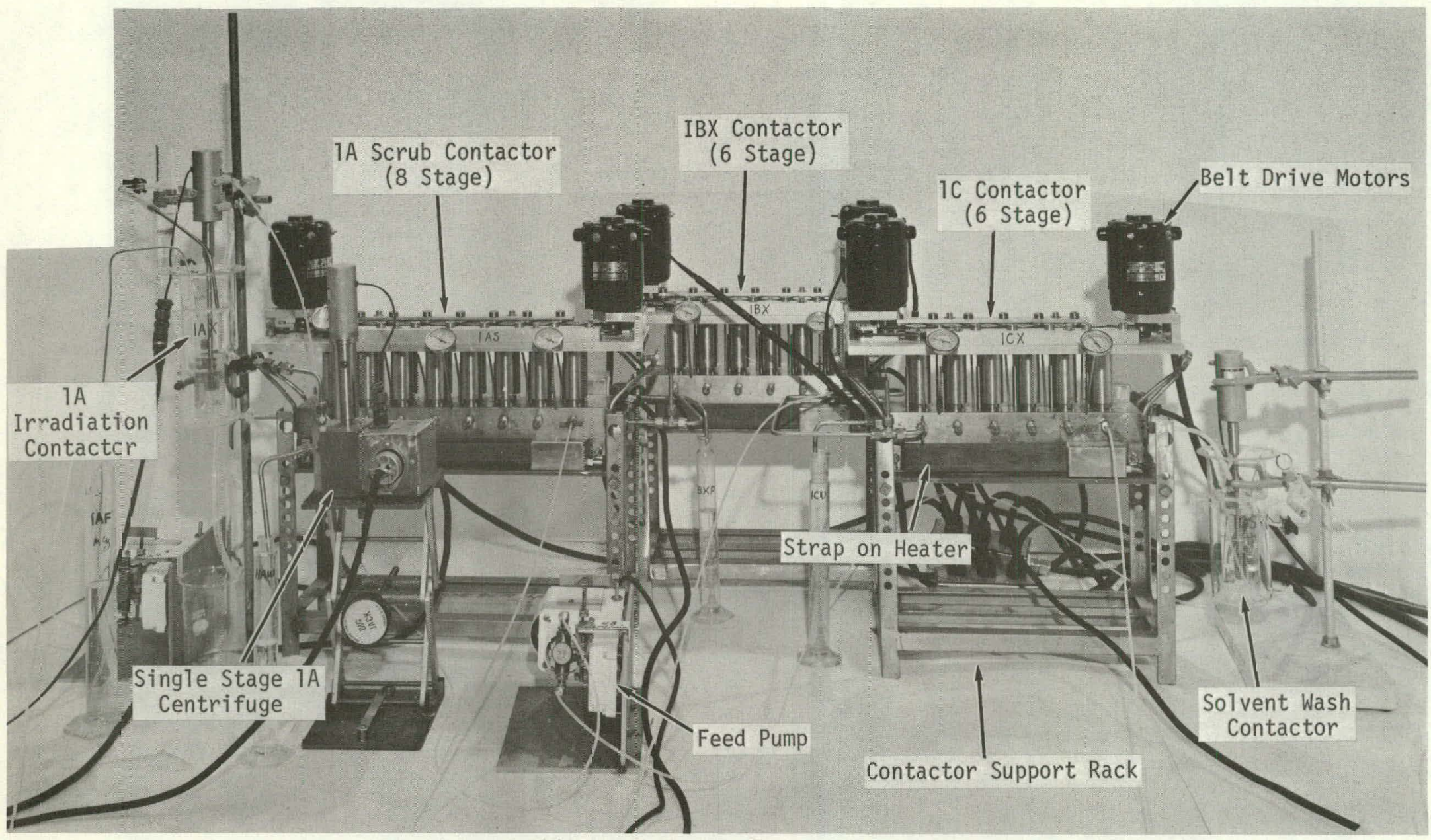

FIGURE 4: "COLD" TEST STAND 


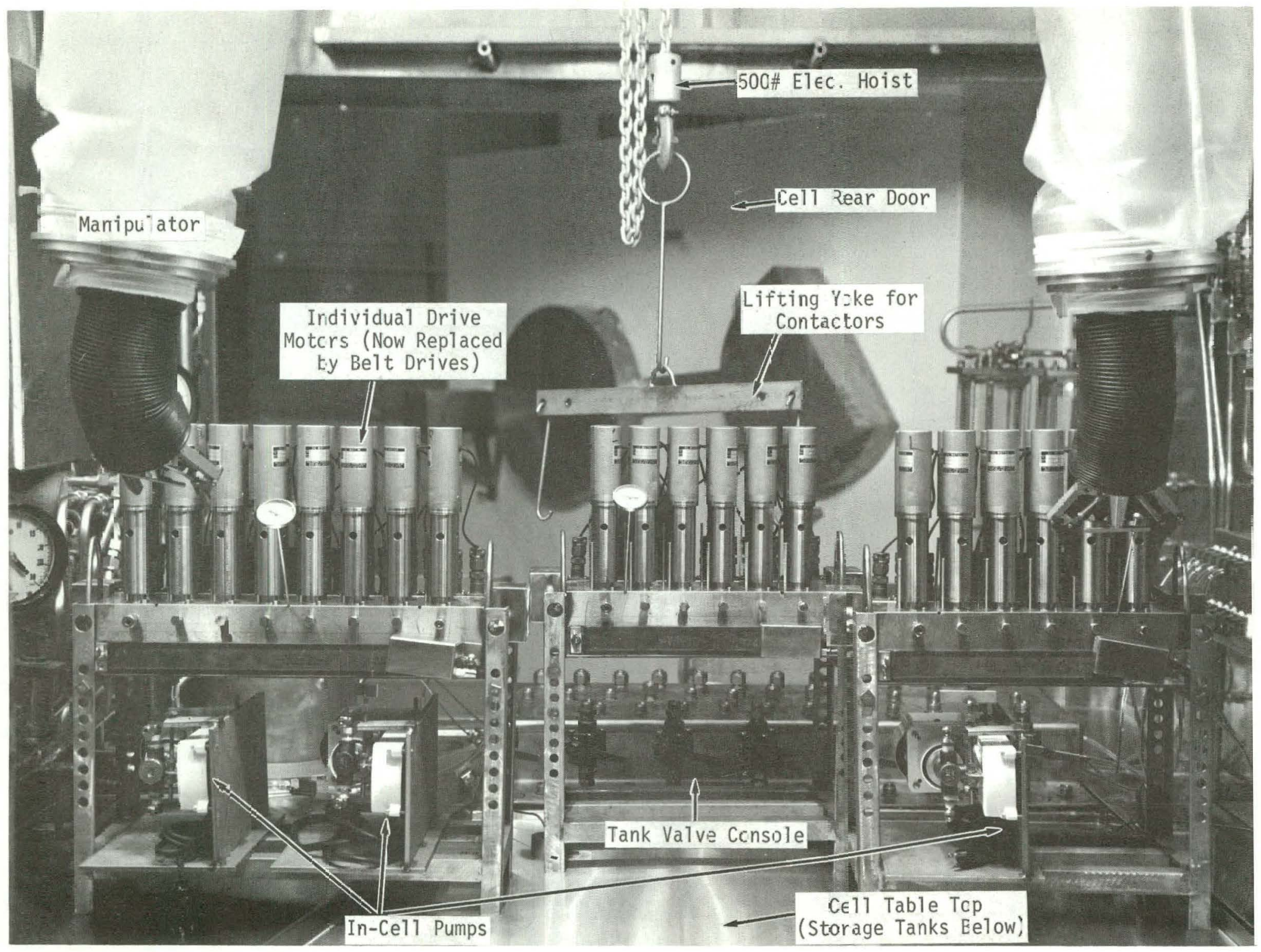

FIGURE 5: TEST STAND MOCK UP IN =-CELL 
section is determined primarily by the density ratio. Calculated total organic holdups in the experimental units under normal Purex flowsheet operating conditions are 33, 28, and $16 \mathrm{ml}$ for the $\mathrm{IA}, \mathrm{IBX}$, and $\mathrm{IC}$ contactors, respectively. The capacity of the SRL contactors is in excess of $100 \mathrm{ml} / \mathrm{min}$, sum of flows. The total flow rates for the test units in the LMFBR study will be about 6 to $10 \mathrm{ml} / \mathrm{min}$ in order to obtain solvent residence times in the various contactors comparable to those in pulse columns.

The centrifugal contactors are particularly attractive for this study because of their wide range of operating flow rates and the small holdup volumes. A close approach to steady-state operation is usually achieved in a continuous, countercurrent operation after about 5 throughputs of feed solutions, or within about two to three hours in our apparatus at the planned flow rates.

\section{FEED MATERIALS AND FLOWSHEETS}

A rare-earth fission product stock solution will be used to obtain aqueaus phase power densities in the IA irradiation contactor comparable to LMFBR dissolver solutions. The rare earth concentrate is produced in Hanford's B-Plant as part of the ARHCO Waste Management Program and will have a power density of about 10 to $15 \mathrm{~W} / \mathrm{liter}$, mostly as CePr-144. It will be well aged at the time of use to assure complete destruction of residual solvent from the separations process. The rare earth feed solution will also contain uranium and nitric acid at concentrations prevaling in the upper mid-section of a $1 A$ column extraction section; it will not contain plutoniam or those fission products which might be precipitated as phosphates.

An irradiated Hanford $\mathrm{N}$-reactor fuel element will be dissolved in the cell and used to provide a complete radio-fission product spectrum for fission product performance studies. Typical IAF solutions will be prepared by blending this solution (containing about $0.5 \mathrm{~W} / \mathrm{liter}$ ) with solvent-free uranium and plutonium stock solutions and appropriate amounts of other chemicals as needed. The power density of the IAF will be adjusted to $<10 \%$ of the cerium feed power density. Feed compositions will simulate the current Hanford Purex Plant IAF and the ORNL-proposed LMFBR IAF compositions. Uranium and plutonium concentrations will be adjusted to 
provide the desired IAP solvent product loading. To avoid criticality problems in the hot cell and its auxiliaries, the plutonium concentration in the LMFBR feed will be kept below $4 \mathrm{~g} / \ell$ for most of the runs. The IAF will be fed to the second stage of the 8-stage $1 A$ contactor, leaving 6 stages available for the scrub section.

Conceptual flowsheets to be used in the test apparatus for processing the two feeds are shown in Figures 6 and 7. The LMFBR flowsheet is based on suggested ORNL flowsheets $(9,10)$ and differs from the Purex flowsheet primarily in the use of 15\% TBP rather than 30\% TBP and the use of a greater reductant flow in the $1 B X$ column. Other flows are adjusted as necessary to match the requirements of the different solvent concentration. No final decision on the normal operating temperature has been made, but provisions have been made for heating the contactors to $50^{\circ} \mathrm{C}$. Operating performance and extraction kinetics are improved by operation at higher temperatures; but chemical degradation of the solvent is also increased, and it may prove more important to operate at ambient temperatures to be able to distinguish better between chemical and radiolytic degradation of the solvent. The ambient cell temperature is expected to be 30 to $35^{\circ} \mathrm{C}$.

The solvent flow rate shown in the flowsheets was set to provide a solvent residence time in the scrub portion of the $T A$ contactor comparable to that in a Purex Plant pulse column, a factor believed to be important because of the slow scrubbing kinetics for certain zirconium species. Most of the Hanford Purex Plant pulse columns have the design capability of operating at superficial organic volume velocities of 500 to $1500 \mathrm{gal} / \mathrm{hr}^{-} \mathrm{ft}^{2}$. The $1 A$ column is operated with the organic phase continuous and occupying about $85 \%$ of the column volume in the contacting section. " This translates

Over many years of operation with glass pulse columns, we have observed that pulsing conditions must be set to give at least $15 \%$ average dispersed phase holdup in order to obtain maximum mass transfer efficiency. Higher holdups are frequently obtainable and are often desirable with certain cartridges or flowsheets to obtain increased efficiency. The $15 \%$ holdup used in example calculations here and in Appendix $B$ is believed to represent the minimum acceptable dispersed phase holdup in the contacting section of a $1 \mathrm{~A}$ pulse column. This number agrees with that obtained using a correlation relating holdup to flooding; (24) however, such correlations provide only rough approximations at best and should be supplemented by actual column data wherever possible. Such data can conveniently be obtained in installed columns by static or differential pressure measurements, which in effect measure the average density of the column contents. 


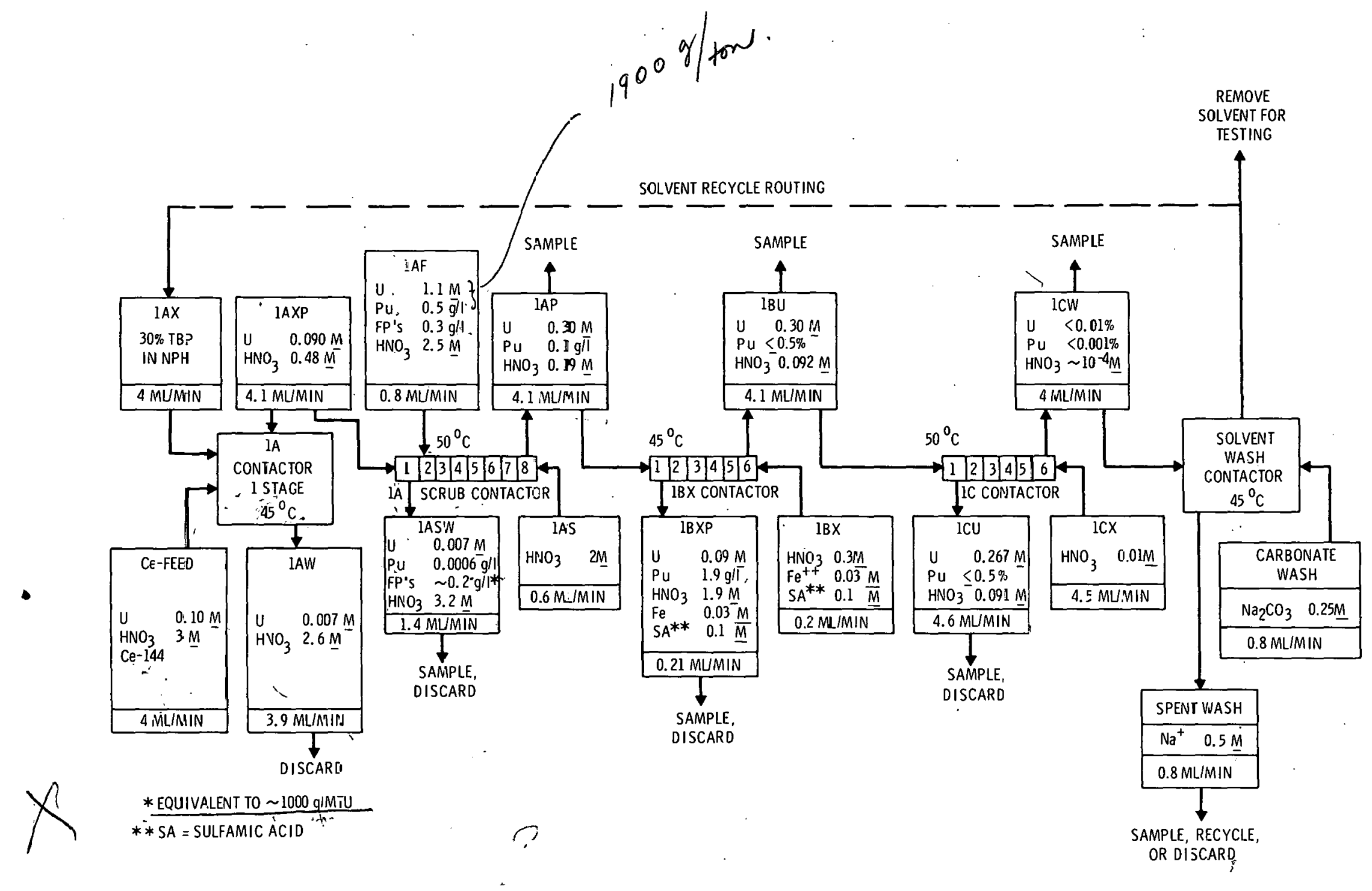

FIGURE 6. HANFORD PUREX FLOWSHEET ADAPTED FOR SOLVENT IRRADIATION TEST 


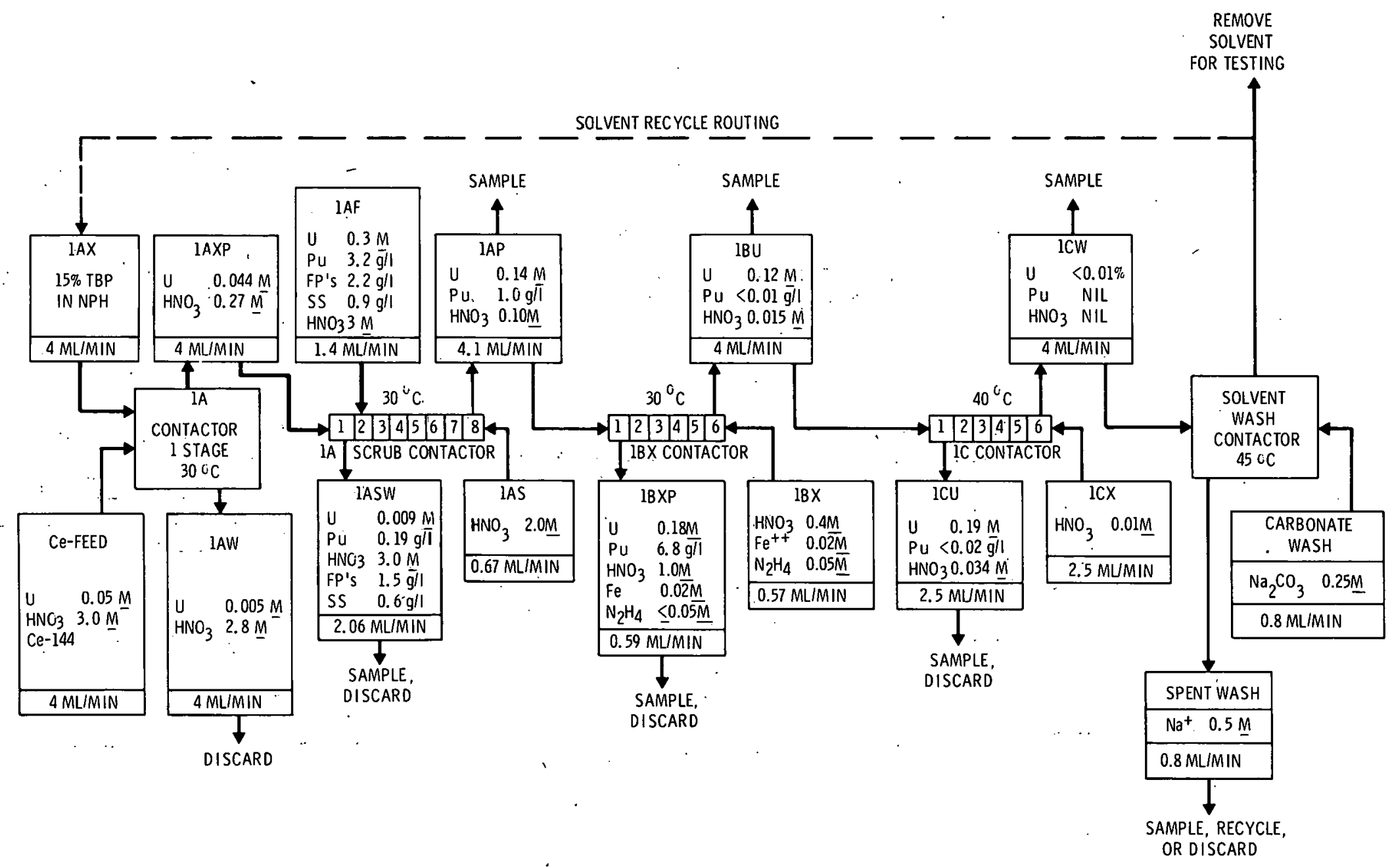

FIGURE 7. ORNL LMFBR FLOWSHEET. ADAPTED FOR SOLVENT IRRADIATION TEST 
to actual linear organic velocities of about 80 to $230 \mathrm{ft} / \mathrm{hr}$. Solvent residence times in the $20-\mathrm{ft}$-tall Plant $1 \mathrm{~A}$ column scrub section would thus range from 0.25 to 0.085 hours. The specified solvent flow of $4 \mathrm{ml} / \mathrm{min}$, together with the calculated $26 \mathrm{ml}$ solvent holdup in the $1 \mathrm{~A}$ scrub contactor, will provide a solvent residence time of $6.5 \mathrm{~min}$, equivalent to that obtained with an organic volume velocity of $1180 \mathrm{gal} / \mathrm{hr}^{-} \mathrm{ft}^{2}$ in the Purex Plant column. Higher solvent rates can and will be tested in the test apparatus to see how much the scrub residence time does limit fission product scrubbing.

The IAF flow rate in the flowsheets was set to equal the solvent flow rate. This will provide equal holdup volumes of solvent and aqueous phases in the single-stage $T A$ contactor and should improve the reliability of absorbed dose calculations, as described in Appendix B. Other flow ratios can and will be used to test the assumption that the radiation dose is absorbed equally by both phases.

OPERATING PROCEDURES

This section summarizes the normal operating procedures as they are visualized at this time.

\section{Feed Preparation}

The cerium and IAF feed solutions will be prepared by careful blending of well-analyzed stock solutions of fission products, uranium, plutonium, nitric acid, and cold chemicals simulating major fission products not adequately represented in the actual fission product stock solutions. The radioactivity for solvent irradiation will be supplied by the CePr-144 stock solution. A separate feed (IAF), derived from a dissolved fuel element, will be added to the 8-stage $1 A$ contactor to provide sufficient ZrNb-95 and RuRh-106 activity for decontamination performance measurements. The IAF will contain at least $100 \mu \mathrm{Ci} / \mathrm{ml}$ of each of these fission products so that normal product DF's on the order of $10^{4}-10^{5}$ can be measured accurately.

The smaller feed batches will be made up in a graduated glass blend tank located on the work table for accuracy in measuring the volumes of fission product solutions added. Larger feed batches, for the longer solvent 
recycle tests, will be made up in a 150 liter storage tank located below the table top. This tank will be fitted with a weight factor instrument for monitoring solution volumes. Solution volumes added to the makeup tank will be measured and added via graduated vessels located on the work table or external to the cell. Feed from this storage tank will be transferred to the feed tank on the work table as required during the run.

\section{$\underline{\text { Startup }}$}

The experimental apparatus will normally contain "cold". solutions left from the previous shut-down procedure. Startup will involve turning on the heaters to heat the various contactors to the desired operating temperature. Agitator motors are then turned on, and "cold" scrub and strip flows are started and adjusted to the desired operating rates. After an operational check to assure the operability of the apparatus, the "hot" cerium and IAF feeds and the solvent will be introduced. Optionally, the solvent and the cerium feed may be started ahead of time to fill the irradiation contactor. Flow rates and heating rates will be adjusted as necessary during this startup period to attain the desired operating conditions. Occasionally, a new run will be started by changing the feed composition, flow rates, or other variables without shutting down between runs.

\section{Normal Operation}

Two modes of operation will be investigated in this program. The first mode will involve determining the effect of increasing dose rates, solvent residence time, etc. on the solvent performance parameters on a once- . through basis for the solvent. In this type of run, the apparatus would be operated just long enough under the given run conditions to assure that steady-state profiles had been obtained. Steady-state gamma profiles will be confirmed by analyzing successive grab samples of solutions leaving each contactor with a shielded and coil imated gamma spectrometer detector installed in the cell. Steady-state plutonium and uranium profiles will be confirmed by conventional analyses of successive grab samples of the effluent phases. The number of samples required to confirm steady state 
should decrease with operating experience. Total run lengths should. not exceed 5 hours per test, and considerably less time should be required for runs involving the change of a single variable without a shutdown between runs (essentially a continuation of the preceding run).

The other mode of operation will involve recycling the solvent continuously throughout the run: In these tests, a minimum inventory of 200-250 $\mathrm{mi}$ of solvent would be placed in the system at the beginning of the run and be recycled continuously by pumping the solvent from the solvent decanter (or washed solvent receiver) to the $1 \mathrm{~A}$ mixer s.tage. Fresh solvent would be added in batches of about $25 \mathrm{ml}$ each to replace losses and samples removed for analyses or testing. Operated in this mode, the solvent will approach a steady-state cumulative absorbed dose after about 10-15 days of operation. Most runs, however, will be terminated before this time if there are no significant changes in solvent properties with time. Alternatively, we can start with a larger inventory of solvent and let it decrease throughout the test without replacement. Radiation levels and solvent residence time in the $I A$ mixer will be adjusted so that the steady-state cumulative dose in the test apparatus approaches or exceeds that that would be attained in an LMFBR processing plant (assuming that the solvent inventory and solvent loss rates are comparable to those in the Hanford Purex Plant). A detailed analysis of the calculations involved is presented in Appendix $A$.

Sampling

Effluent samples from each contactor, particularly of the solvent phàse, will be taken frequently to determine changes in the gamma spectrum caused by, approach to steady-state or cumulative solvent exposure. These will be placed in a cell-holder of fixed geometry and counted in the cell by a gamma spectrometer detector installed in the rear door of the cell and a 400-channel analyzer located outside the cell. More precise analyses for gamma emitters, as well as for uranium and plutonium, will be performed on selected samples removed from the cell. Analytical methods and expected precisions are described in Appendix $D$.

Bulk samples of solvent will also be removed from the cell for measurement of physical properties (density, viscosity, etc.), standard distribution 
ratio tests, and for the development of improved solvent washing techniques. We expect to be able to remove liter quantities of used, carbonate-washed solvent from the cell with little or no protective shielding required.

The optimum frequency of sampling will be determined in early tests.

Shutdown

At the conclusion of a test run, the feed streams to the $1 A$ mixer stage and the agitator will be shut off momentarily to measure phase disengaging times at the steady-state solvent dose and to confirm that the steady-state phase volume ratio in the mixer was the same as the flow ratio. If no further runs are planned for that day, the "hot" feed will be displaced by running a "cold" feed (plutonium-free) for about an hour under otherwise normal operating conditions. The apparatus would then be shut down with the uranium and nitric acid profiles stili at steady state. In some cases, the mixer stage will be emptied and replaced by a differentsized mixer before the next run.

\section{Waste Disposal}

High-level aqueous waste from the $1 \mathrm{~A}$ contactor will be collected in a storage tank below the work table. Periodically this waste will be transferred to another storage tank in a vault below the cell and, eventually, to a shielded cask for disposal. The spent aqueous solution from the multistage $1 A$ contactor and the spent carbonate solution from solvent washing will be combined with this waste. Other aqueous effluent streams containing uranium and plutonium will be removed from the cell and returned to the Hanford Purex Plant or disposed of as separate waste streams, depending on the product value. All solvent wastes will be removed from the cell for further testing or for disposal via a separate waste system. The only effluent stream to be reused throughout this study will be the solvent stream; all aqueous effluent streams will be discarded to avoid the possibility of recycling an unknown amount of degraded solvent that might be entrained or dissolved in the aqueous effluents. 
DOSIMETRY MEASUREMENTS AND CALCULATIONS

The solvent radiation exposure will be calculated by the method described by Blake. (1) The procedure involves calculating the radiation power density in the mixer and multiplying it by the time that the organic phase remains in the extraction zone. The steps outlined by Blake are as follows:

1. Obtain the average beta and gamma power densities in the blended IAF solution. In our case, this will be obtained by careful laboratory analysis of the radioactive fission products in the high-level waste stock solutions.

2. Calculate the beta and gamma power densities in the mixing section of the extraction apparatus by multiplying the power density of the aqueous feed by the aqueous feed fraction of the combined feed, scrub (if present), and organic-phase volumes in the mixer. Thus, if the actual volume ratios of feed, scrub, and organic streams present in the mixer are 1:1:2, the power density in the mixer is one-fourth that of the feed. It is assumed that droplets of the dispersed phase are infinitely small and, therefore, that each molecule in the mixed solution exists in a field having this power density, regardless of whether the molecule is from the organic or aqueous phase. Implicit in this assumption is the necessity for the size of each dispersed aqueous droplet to be considerably less than the path length of the beta particle. Our system should meet this criteria since the average beta energy of CePr-144 is about $1.1 \mathrm{MeV}$, the estimated average beta energy of our feed will be about $1 \mathrm{MeV}$, and the maximum range of a $1 \mathrm{MeV}$ beta particle is about $4 \mathrm{~mm},(11)$ about 7 times the maximum drop diameter measured in one of our test mixers.

3. Calculate an effective radiation power density to account for the escape of some of the radiation energy from the system. It is customary to assume that the mixed phases absorb all (or nearly all) of the beta energy. On the other hand, only a portion of the gamma energy is absorbed, the fraction depending upon the geometry of the system. In our case, with mixer diameters under 2 inches, we expect most of the gamma energy to escape from the system. However, over 
$90 \%$ of the total radiation power density of our feed will be supplied by $\mathrm{CePr}-144$, and over $95 \%$ of its radiation power is due to its beta energy; thus, neglecting the gamma energy in our calculations should have little or no effect on the calculation accuracy. A more detailed discussion of the factors we will consider in evaluating the effective radiation power density is presented in Appendix $C$.

4. Calculate the radiation dose in watt-hours per liter by multiplying the effective power density by the residence time of the organic phase in the mixing section.

The equation for this radiation dose follows:

$$
E=t_{m}\left(G_{B} D_{B}+G_{\gamma} D_{\gamma}\right) P=t_{m} D^{P}
$$

where $E$ = exposure of organic phase during mixing (W-hr/liter)

$t_{m}=$ residence time of the organic phase in mixer $(h r)$

$D_{B}=$ beta power density in aqueous feed (watts/liter)

$D_{\gamma}=$ gamma power density in aqueous feed (watts/liter)

$D_{e}=$ effective total power density in aqueous feed (watts/liter)

$G=$ fraction of beta or gamma radiation absorbed in mixer

$P=$ aqueous feed volume fraction in mixer.

Radiation doses calculated by using this equation will still be approximate values because of inaccuracies both in the equation and in the quantities used in the equation. This equation, however, is the best available method for pulse column solvent dose calculations, and relative errors will be minimized by using the same calculation method for our test stand dose calculations.

Appropriate corrections to the above equation are usually supplied to account for exposure during phase disengagement. The use of a miniature centrifuge in our apparatus to separate the mixed phases immediately after leaving the mixer will minimize this exposure time. We will attempt to estimate the incremental dose received by the solvent in the centrifuge; however, the residence time $(\leq 20 \mathrm{sec})$ is so short that the incremental dose should be negligible. The incremental dose from the separate IAF stream will also be estimated (should be $<5 \%$ of the total dose). 
Solvent radiation exposure in succeeding contactors due to extracted and entrained radioactivity and that due to plutonium is small and usually ignored. In our case, it should amount to less than $1 \%$ of the total exposure per pass.

Calculations of this type were made to estimate solvent exposures obtained in Hanford-type pulse columns when operated under current Purex process conditions and that would be obtained with a typical LMFBR flowsheet. The results are summarized in Appendix $B$. The results show that solvent dose rates per pass would be about 0.005 and $0.1 \mathrm{~W}$-hr/liter for the two respective flowsheets ( \pm a factor of two, depending on the assumed feed activity and processing rates). These results agree with the results of similar calculations made at ORNL. (8)

A series of special dosimetry runs is planned at the start of the "hot"-cell operations to try to confirm the calculated absorbed solvent radiation dose. This will be done by measuring the amount of DBP and MBP (di- and mono-butyl phosphates) formed as a function of the calculated average radiation power density in the mixer and the solvent residence time. The results will be compared with published G-values for radiation decomposition of TBP. (Laboratory determination of TBP G-values may be included in this study to minimize any bias that might be introduced by DBP-MBP analytical methods used by the various researchers.) As currently visualized, the dosimetry runs would involve operation of the $1 A$ mixer and scrub contactors only, using fresh solvent and various dilutions of the CePr-144 fission product stock solution. Uranium, plutonium, and other fission products would be omitted to simplify analyses. At least two different volumetric flow ratios will be used to check the assumption that the radiation dose is absorbed equally in both phases.

Relatively high dose rates will be used in the dosimetry runs to improve the accuracy of $G(D B P)$ measurements. We expect to generate about 200-300 $\mathrm{mg}$ $\mathrm{DBP} / \mathrm{W}-\mathrm{hr}$ in our dosimetry tests. (12) At our proposed dose rates, we should find about 20 to $600 \mathrm{mg} \mathrm{DBP} / \ell$ in the irradiated solvent. We plan to use a modification of the methylation procedure developed by Kibbey and Davis (4) to analyze DBP. The precision of our method hasn' $t$ been determined yet but should equal or exceed the published value $( \pm 0.95 \mathrm{mg}$ over the range 6.5 to $32.5 \mathrm{mg}$ of DBP). 


\section{TENTATIVE RUN SCHEDULE}

The following list is a rather broad outline of the number and types of runs that are currently planned for the initial testing program. Additional runs will be planned where warranted (including replicate runs to establish the amount of random variation in decontamination and losses) to study such variables as diluent composition, temperature effects, etc.

\section{TBP Dosimetry}

Type of Run
Single-Pass $\frac{\begin{array}{c}\text { Approximate } \\ \text { Number }\end{array}}{6} \frac{\ldots \ldots \ldots \text { Variables Tested }}{\begin{array}{l}\text { Average radiation power level }: 0.5 \text { to } 5 \mathrm{~W} / \mathrm{l} \\ \text { Solvent residence time: } 4 \text { to } 40 \mathrm{~min} . \\ \text { A/O volume ratio: } 0.5 \text { and } 1 .\end{array}}$

Current Purex Process Flowsheet ( $30 \%$ TBP)

Single-Pass . $\quad 5-10$

Recycle

1

LMFBR Flowsheet (15\% TBP)

Average radiation power leve $1: 0.05$ to $1 \mathrm{~W} / \mathrm{l}$. Solvent residence time: 1 to $12 \mathrm{~min}$. Solvent flow rate: 4 to $20 \mathrm{ml} / \mathrm{min}$. Range of absorbed solvent dose to overlap that for LMFBR tests: 0.003 to $0.1 \mathrm{~W}-\mathrm{hr} / \mathrm{l}$.

Cumulative solvent exposure to about $4 \mathrm{~W}-\mathrm{hr} / \mathrm{l}$. (Additional runs may be planned to cover higher cumulative exposure at higher radiation power levels.)

Single-Pass $\quad 10-15$

$$
\begin{aligned}
& \text { Single-Pass } \\
& \text { Recycle }
\end{aligned}
$$

Recycle
5

3- 5
Average radiation power leve $1: 0.25$ to $5 \mathrm{~W} / \mathrm{l}$. Solvent residence time: 1 to $25 \mathrm{~min}$. Solvent flow rate: 2 to $16 \mathrm{ml} / \mathrm{min}$. Total absorbed dose: 0.02 to $2 \mathrm{~W}-\mathrm{hr} / \mathrm{l}$.

Solvent washing technique (involves single-pass recycle of once-used solvent after being washed by various techniques).

Cumulative solvent exposure to about $80 \mathrm{~W}$-hr/liter at two or more radiation power levels and 2 or more solvent residence times. 
Several combinations of solvent residence time and average power levels giving the same calculated absorbed solvent dose will be tested to determine whether the effect of radiation depends only on the absorbed dose/pass or also on the rate the dose was received. A conceptual list of run conditions is presented in Tables II and III. These tables were prepared as a guide for planning and scheduling purposes, and may not be representative in detafl of the final list of runs.

\section{PERFORMANCE CRITERIA}

The effect of radiation on solvent performance wil1 be measured by the effect of a progressively increasing dose (both single-pass and cumulative during recycle) on the following parameters:

1. The zirconium, niobium, and ruthenium decontamination factors in the IAP and the uranium and plutonium product streams (ICU and IBXP).

2. The plutonium loss to the uranium product stream (1CU).

3. The uranium (and plutonium) loss to the $1 C$ column stripped solvent $(1 \mathrm{CW})$.

4. The accumulation of activity in the stripped solvent (1CW) before and after carbonate washing.

5. The density and viscosity of the washed solvent.

6. The phase disengaging times in the $1 \mathrm{~A}$ contactor.

In addition, we will withdraw macro samples of solvent at various times for additional dispersion-disengagement time tests, batch distribution ratio tests, solvent washing (fission-product retention) tests, plutonium retention tests, and other tests as warranted.

The goal of our program is to demonstrate, on a continuous, miniature scale, how the performance of the first cycle of a Purex process is affected by increasing solvent radiation exposure, both. instantaneous and on a long-term, cumulative basis. The parameters we haye chosen to observe are those we consider most important to a fuel reprocessor; namely, the decontamination and product recovery performance and those factors (disengaging times, viscosity, density) most likely to affect the operating (flooding) capacity of the plant columns. The performance of the miniature system will be 
TABLE II

TENTATIVE RUN CONDITIONS - SINGLE PASS TESTS

Aqueous/Organic flow ratio $=1$ in mixer; temperature $=30^{\circ} \mathrm{C}$, except as noted.

$v_{m}$, Mixer, F, Solv. Flnw, $t_{m}$. Solv. Resid. De, lAF Activity, E, Solv. Dose,

Run No. Size; Me me/hr Time;Min. Watts/liter W Whr/liter

Remarks

TBP Dosimetry (30\% TBP): 21 month required

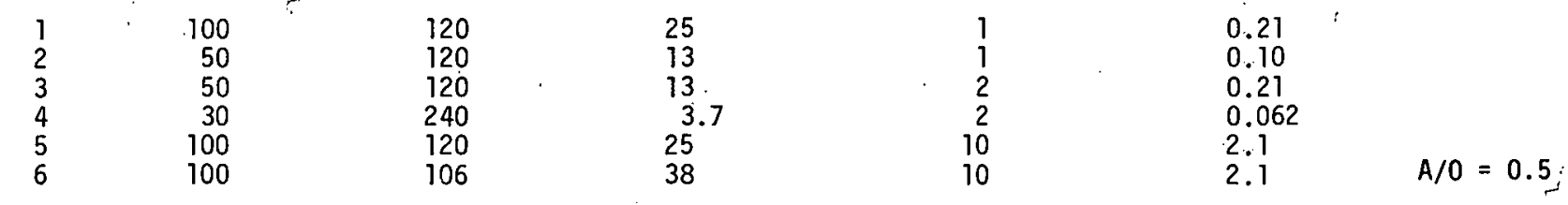

Purex Flowsheet $\left(30 \%\right.$ TBP): $\sim 2$ months required $\left(50^{\circ} \mathrm{C}\right)$

$\begin{array}{rrrr}7 & 30 & 240 & 3.7 \\ 8 & 50 & 240 & 6.2 \\ 9 & 100 & 240 & 12.5 \\ 10 & 30 & 240 & 3.7 \\ 11 & 50 & 240 & 6.2 \\ 12 & 50 & 480 & 3.1 \\ 13 & 50 & 240 & 6.2 \\ 14 & 50 & 1200 & 1.2 \\ 15 & 50 & 240 & 6.2 \\ 16 & 30 & 240 & 3.7\end{array}$

3.7

12.5

3.7

6.2

6.2

6.2

3.7

LMFBR Flowsheet (15\% TBP): i3 months required

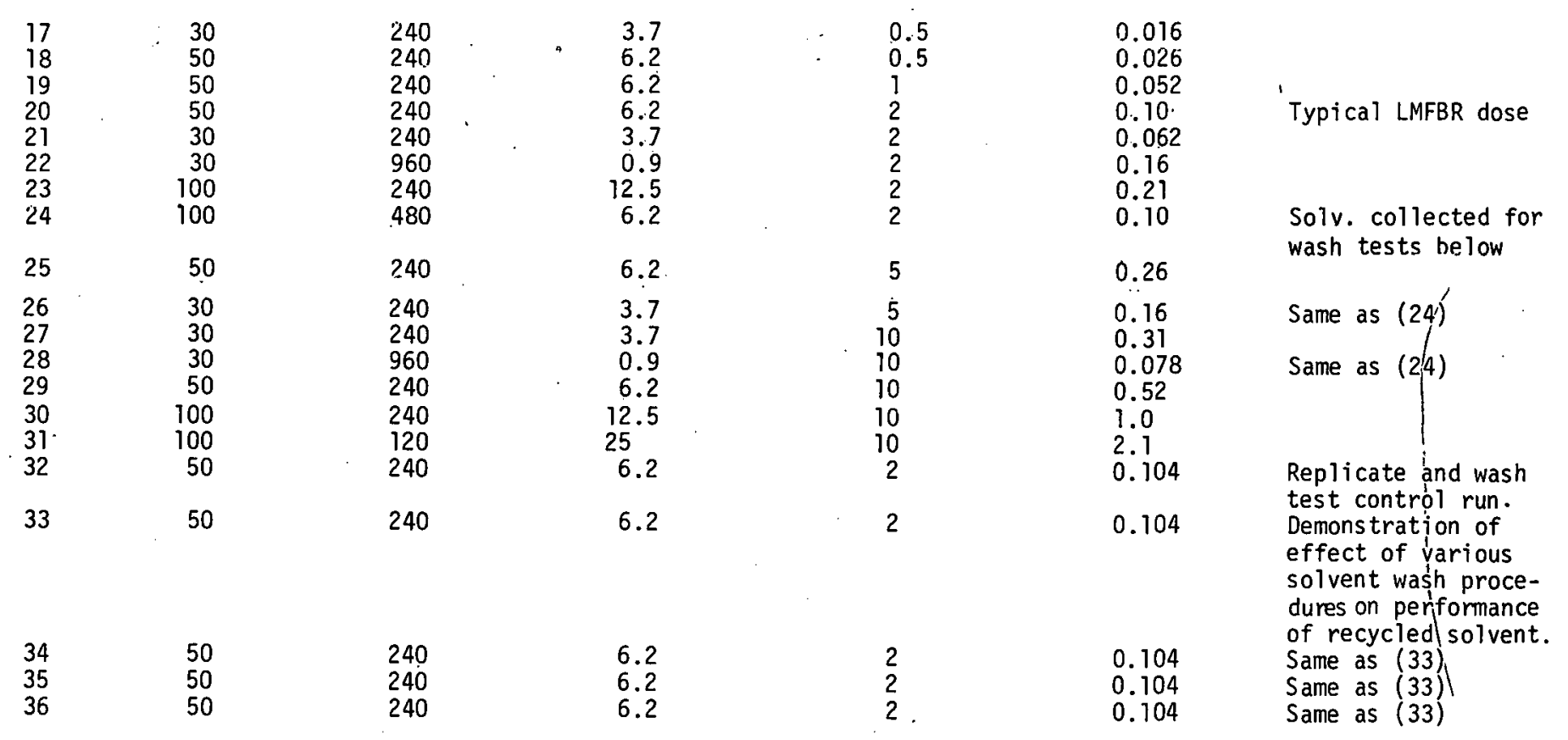


TABLE. III

\section{RECYCLED TESTS}

\begin{tabular}{|c|c|c|c|c|c|}
\hline & $V_{m}$, Mixer & F, Solve & $t_{m}$, Solvent & $\begin{array}{r}D_{e}, 1 A F \\
\text { Activity, }\end{array}$ & Solvent Dose, $W$-hr/liter \\
\hline un $\mathrm{No}$. & Size, $m l$ & Flow, $\mathrm{ml} / \mathrm{hr}$ & Residence Time, min & Watts/liter & Cumulative \\
\hline
\end{tabular}

Purex Flowsheet (30\% TBP): il month required

$\begin{array}{lll}1 & 50 & 240\end{array}$

6.2

0.6

0.031

4

LMFBR Flowsheet ( $15 \%$ TBP): 23 months required

$\begin{array}{lrrr}2 & 50 & 120 & 12.5 \\ 3 & 100 & 240 & 12.5 \\ 4 & 100 & 240 & 12.5 \\ 5 & 100 & 120 & 25 \\ 6 & 100 & 120 & 25\end{array}$

0.83

0.62

0.42

0.83

$2 \quad 0.42 \quad 50$

80

80

80

$4-0.83$
$2-\quad 80$


compared with that of the Hanford Purex plant at similar solvent exposures to provide a reference scale as to the validity of the results. A sufficient range of radiation exposures will be studied to permit extrapolation of the results to zero activity levels so that the chemical degradation effects can be distinguished from the radiolytic degradation effects. The following discussion summarizes the significance of the chosen performance criteria and some of the measurement uncertainties.

\section{General Discussion}

The major effect of radiation on the solvent is expected to be the radiolytic decomposition of the TBP to DBP, MBP, phosphoric acid, and butanol. Of these, only DBP is expected to be present in sufficient quantity to seriously affect separations performance. Some diluent attack can also be expected but will be minimized by the use of a normal paraffin diluent ( $n$-dodecane or a mixture of $\mathrm{C}-10$ to $\mathrm{C}-14$ paraffin hydrocarbons). DBP affects separations performance in several ways:

- It forms strong complexes with zirconium, plutonium, and uranium (strength decreasing in approximately that order).

- The complexes are strongly organic-favoring and result in the retention of these three constituents in the solvent.

- This in turn leads to decreased $\mathrm{Zr}-95 \mathrm{DF}^{\prime} \mathrm{s}$ and increased uranium and plutonium loss to the solvent wash system.

- A number of metal-DBP complexes are only sparingly soluble in the solvent, forming waxy, surface-favoring precipitates.

- The surfactant properties of some DBP complexes can lead to pulse column flooding through forming stable emulsions (notably the Zr-DBP complex).

- The formation of fission product-DBP precipitates can lead to occasional bursts of activity. in the products through physical entrainment of surfactant, interface-seeking films.

DBP is one of a series of organic phosphoric acids that have received considerable study recently. The most widely studied and used analog is HDEHP (di-2-ethylhexyl phosphoric acid). (16) These acids are typically dimeric 
in hydrocarbon diluents, they form strong complexes with most metal ions with the strength increasing generally with increasing metal ion valence, and they react with basic solutions to form aqueous-soluble sodium salts. Equilibrium data for the extraction of metal ions into organic phases containing these organic phosphoric acids are usually correlated by mass action constants based on the two-phase chemical reaction:

$$
M^{+a}+\underline{a(H R)_{2}}+\ddot{M(H R 2) a}+a H^{+},
$$

where the underlined compounds represent organic phase compositions, $M$ is the metal ion, and $\mathrm{R}$. is the organic phosphate radical. In molar concentration units, the corresponding mass action constant is

$$
K_{\text {eq }}^{\prime}=\frac{\cdots\left(M\left(H_{2}\right)_{\dot{a}}\right)\left(H^{+}\right)^{a}}{\left(M^{+a}\right)\left((H R)_{2}\right)^{a}}=D_{m}\left[\left(H^{+}\right) /\left((H R)_{2}\right)\right]^{a}
$$

where $D_{m}$ is the organic/aqueous distribution ratio of the metal ion.

The degree of extraction of most metal ions forming DBP complexes is highly dependent on the acidity of the aqueous solution and the concentration of free, uncomplexed H.DBP in the organic phase. This latter term is dependent on the amount of total DBP in the system as well as on the amount of DBP complexed by competing metal ions. The presence of a large amount of uranium or plutonium in the system, for example, will depress the formation and extraction of $\mathrm{Zr}$-DBP.

There are exceptions to these rules. Zirconium extraction by DBP was reported by Hardy and Scargily(17) to be independent of the hydrogen ion concentration, probably because of its prevalence as hydrolyzed species at low acidities. The observed extraction behavior was interpreted to follow the reaction:

$$
\mathrm{ZrO}^{2+}+2(\mathrm{HDBP})_{2}+2 \mathrm{NO}_{3}^{-}+\left[\mathrm{Zr}\left(\mathrm{NO}_{3}\right)_{2} \cdot(\mathrm{DBP} \cdot \mathrm{HDBP})_{2}\right]+\mathrm{H}_{2} \mathrm{O}
$$

Some metals (notably uranium) also form solvation complexes with acid phosphates at high nitric acid normalities comparable to the TBP solvation complexes. (14) This effect is probably not of great importance at the acidities we will use in our tests. 
MBP forms metal complexes similar to those with DBP, but it has been considerably less studied. It is formed in minor amounts, (generally $<20 \%$ of the amount of DBP), ${ }^{(2)}$ and its effects on process performance are not usually considered separately from the effects of DBP.

Although we will be using a very stable diluent, prolonged degradation studies and Purex plant experience indicate that a small amount of fission product zirconium, niobium, and ruthenium become "fixed" in the solvent. Unlike DBP, the ligands causing this effect are incompletely removed by washing the solvent with carbonate or hydroxide solutions. We expect to distinguish the growth of any such ligands in our solvent by measuring fission product retention after extensive alkaline solvent washing. Although the fission product-ligand complexes are strongly solvent favoring, they do have finite distribution ratios between the two phases and can be one of the major factors limiting the overall fission product DF's to the aqueous product of a solvent extraction cycle.

With the above discussion as background, it may be appropriate now to discuss the individual performance criteria specified in the Program Plan. These were chosen specifically because we consider them to be of most importance to a potential fuel reprocessor:

- The individual fission product $D F^{\prime} s$ because they may determine whether the desired overall decontamination can be accomplished in the normal two or three solvent extraction cycles;

o. the plutonium loss to the ICU stream because this may affect plutonium contamination in the final uranium product or, in a worst case, cause criticality problems in the uranium cleanup system;

- the uranium and plutonium loss to the $1 \mathrm{CW}$ because this will normally represent a process loss to the solvent treatment waste;

- the accumulation of activity in the stripped solvent before and after washing with alkaline solutions as an indirect measure of the relative amounts of DBP-MBP and diluent degradation ligands;

- the density and viscosity of the washed solvent as a measure of physical changes in the solvent that may affect flooding or capacity of the Plant solvent extraction contactors; and 
- the phase disengaging times in the TA contactor as a measure of the formation of surfactants that might affect emulsification tendencies or mass transfer rates.

\section{Fission Product Decontamination Factors (DF's)}

Formation of DBP should have a'major effect on the Zr-95 DF, a lesser effect on the Nb-95 DF, and probably little or no effect on the Ru-103,106 DF. $(14,15)$ DF's from all other fission products, including the 'CePr-144 used to provide the majority of the radioactivity in the tests, should be very high (greater than $10^{5}$ ) and virtually unaffected by solvent degradation. With all of the metal constituents of the feed held constant, the $\mathrm{Zr}$ DF to the IAP should decrease proportionately to the increase in the solvent dose. We have six scrub stages available to assure that all of the normal zirconium and other fission product species are removed before making this first retention test. Laboratory and pilot plant experience has shown that very little DF improvement is obtained by increasing the number of effective stages beyond 6 ; thus an increase in fission product retention should be a direct measure of an increase in complexing ligands in the solvent. We intend to confirm this by batch scrubbing selected samples of the IAP and measuring the fission product distribution ratios.

A summary of the expected analytical precision of gamma analyses is presented in Appendix D. We foresee no difficulties in analyzing any of the organic streams or aqueous product streams due to interference from the macro amounts of CePr-144 in the feed. The mixed-fission product fraction will be obtained from a fuel element of known irradiation history, and the fission product activities will be calculated and compared with the analytical vàlues:

The total amount of fission product elements in the feed will be supplemented with cold chemicals to the levels expected in LMFBR fuels. Ruthenium and zirconium will be added during the dissolution step to promote isotopic interchange. A major limitation of the measurement technique may lie in how well these simulated fission products (as well as those obtained from the uranium metal fuel element) simulate actual LMFBR dissolver solutions. It is well known that the dissolution technique, 
digestion, acidity, etc. can have a pronounced effect on $\mathrm{Zr}, \mathrm{Nb}$, and Ru performance. $(14,15)$ In the case of zirconium and niobium, the effect may be due to the formation of a variety of hydrolytic species. Ruthenium chemistry is more complex; a wide variety of nitro, nitroso, nitrato, etc. species have been identified; and several are quite extractable in TBP. Ideally, the final feed mixture should be digested at elevated temperature for several hours to assure an isotopic interchange between the "hot"fand simulated fission product species, but we are not sure yet whether this will be feasible to do on a routine basis or necessary. The actual simulation of the fission product species present in an LMFBR dissolver solution is not as important as maintaining a constant ratio of such species so that variations in DF due to different species behavior do not mask the effect of solvent degradation.

Behavior of extracted hydrolytic species of zirconium and especially niobium are believed to be responsible for much of the apparent random variation of ZrNb-95 DF's in years past. One possible interpretation of the data is that these species have a very small distribution ratio into the organic phase but once there are difficult to remove because of their polymeric size and low diffusivities. The efficiency of removal would depend on the degree of agitation $n r$ phase dispersion and on contact time. Very possibly some of these species extract normally but hydrolyze or polymerize in the organic phase before they can be scrubbed. We hope to minimize trouble in this respect by using uniform contacting conditions. Residence time effects will be studied by operating the scrub and strip contactors at different flow rates for a limited number of tests. Residence or contact times may also affect ruthenium behavior through a slow equilibrium interchange between species.

Another explanation of erratic ZrNb-95 behavior lies in the affinity of these fission products for interfacial solids and in their formation of precipitates or surface-forming compounds with solvent degradation ligands. At high dose rates, we may expect to see increasing random variations in ZrNb-95 activities in solvent raffinate streams due to precipitation or. adsorption on contactor surfaces. Entrainment of interfacial solids or precipitates in the solvent or aqueous product samples would result in 
erratic fission product activities in successive samples and should be detectable for that reason.

A steady-state level of such solids should tend to accumulate in the contactors at a given dose rate. Activity would tend to leach from these solids at a fairly constant rate, adding another measure of uncertainty to the results, particularly if a low-dose run follows a high-dose run. We hope to minimize this effect by frequent replacement of the irradiation vessel, by periodically decontaminating the contactors, and by running low dose-rate runs first.

Fission product decontamination in the subsequent $\mathrm{IBX}$ and $1 \mathrm{C}$ contactors will help indicate how tightly the fission products were held in the solvent by the degradation products. In the Purex Plant at Hanford, about half of the fission products in the scrubbed solvent follow the partitioned plutonium stream and perhaps half of that remaining in the solvent is stripped with the uranium in the $i c$ contactor. Even with high distribution ratios, some of the "fixed" fission products wi.l be stripped; the relative concentrations in the organic and aqueous effluent streams being approximately equal to the organic/aqueous distribution ratio.

\section{Plutonium Loss to the Uranium Product}

DBP should not affect the ability to partition plutonium from uranium. Laboratory studies have shown that DBP does not interfere with the reduction of plutonium in the presence of macro uranium and that $\mathrm{Pu}$ (III) is not appreciably complexed by $\mathrm{DBP}$ in the $\mathrm{U}_{-\mathrm{HNO}}$ system. $(12,18)$. In the absence of competing metal ions, however, it is very difficult to reduce and strip the plutonium from DBP-contaminated solvent. It seems advisable, therefore, to investigate the ability to strip the plutonium from the irradiated solvent in a $1 B X$ contactor to assure ourselves that DBP or other solvent degradation products do not interfere with $\mathrm{Pu}(\mathrm{IV})$ to $\mathrm{Pu}(\mathrm{III})$ reduction. Six stages should be sufficient to remove all of the readily reduced and strippable plutonium so that an increase in plutonium concentration in the uranium product (ICU) and in the ICW streams above some to-be-determined flowsheet level should be a measure of this effect. Batch equilibrations of effluent streams will be made periodically to establish whether plutonium losses were due to solvent impurities or to malfunction of the contactors. 
Plutonium retention may also depend on the plutonium/uranium concentration ratio because of the competition between them for DBP or other solvent ligands. We plan to run one or more runs at the full LMFBR plutonium concentration to determine the magnitude of this effect. Uranium and Plutonium Loss to the IC Contactor

The presence of DBP will increase the uranium loss to the 1CW stream. A number of studies have been made showing the effect of various concentrations of uranium, DBP and TBP on the uranium distribution ratio under $1 C$ column conditions. $(19,20)$ The results of these studies will be used to interpret the analyzed uranium retention values. A preliminary evaluation indicates that our maximum anticipated DBP concentration of about $600 \mathrm{mg} / \mathrm{l}$ should increase the uranium loss from $<0.02 \mathrm{~g} / \ell$ to about $0.3 \mathrm{~g} / \ell$ in the $1 \mathrm{CW}$. Uranium retention in degraded solvent is not necessarily linear with increased radiation dose or DBP concentration. DBP and uranium-DBP complexes have a small but definite distribution ratio to the aqueous phase that increases with decreased $\mathrm{HNO}_{3}$, DBP, and TBP concentrations. (19) Also, published studies ${ }^{(23)}$ indicate that a "phosphate radiation polymer" which also complexes and holds uranium in the solvent may be formed. Apparently this is not acidic and could build up in recycled solvent.

As indicated with other retention tests, we will periodically make distribution ratio measurements of stripped solvent to see if high uranium concentrations are caused by abnormal distribution ratios or by poor contactor performance.

Plutonium retention in the $1 \mathrm{CW}$ will be measured to help determine the mechanism by which plutonium was not stripped in the IBX column. Accumulation of Activity in ICW and Carbonate-Washed Solvent (I00)

As indicated earlier, the ability to wash fission products from the solvent by $\mathrm{Na}_{2} \mathrm{CO}_{3}$ solutions should serve to distinguish between $\mathrm{DBP}$ and diluent complexing ligands. This test will be especially important in recycle tests to determine if such ligands continue to build up with cumulative dose rate or reach an equilibrium level determined either by solvent replenishment rate or by the complete degradation of an easily degraded trace impurity in the TBP or diluent. Increasing solvent activity with recycle would be a major consideration in the ability of a plant to maintain a consistently high DF. 
A special plutonium retention test, similar to that used as a process control index of solvent quality in the Hanford Purex plant, will also be made on selected I00 samples. The test involves contacting the washed solvent with a standard aqueous plutonium solution and measuring the amount of plutonium remaining in the solvent after a specified series of stripping contacts. This test should be especially helpful in determining the relative effectiveness of various solvent washing or other solvent cleanup procedures. It is currently being used by Schulz ${ }^{(27)}$ to demonstrate the excellent cleanup of used solvent that can be obtained with macroreticular anion exchange resins.

\section{Physical Properties of Washed Solvent}

Physical properties of irradiated solvent, such as density and viscosity, would be of interest to a reprocessor because of their effect on flooding. capacity of the contactors. Pulse and packed column flooding correlations as a function of such variables have been published, (22) but we have found them of little value in applying them to plant performance: partly because of the gross effect of uranium and $\mathrm{HNO}_{3}$ mass transfer on dispersion and disengaging properties and partly because trace impurities, surface wetting properties of the plate or packing material, etc.; may have an overriding effect on the flooding capacity. A $1 A$ extraction column, for example, has a much higher volumetric capacity than a $1 C$ stripping column because of high uranium and nitric acid mass transfer rates in the $1 A$ column. $A$ IB extraction column has a lower (and often much more variable) capacity than a IC column because of low mass-transfer rates and an apparently greater sensitivity to the effects of trace impurities or plate wetting properties. We do not expect to be able to correlate the physical property data we will obtain with Hanford Purex Plant performance because of these limitations and the scarcity of actual plant performance data as a function of these variables. In Situ Disengaging Times in the IA Contactor

This test will be reported as an indication of the formation of a surfactant in the $\mathrm{IA}$ contactor. Such a surfactant may leave the system via the aqueous raffinate and thus not be observed in similar laboratory tests mentioned below. This is a simple test, but we may not be able to relate the results quantitatively to $1 \mathrm{~A}$ column dispersion performance. Certainly a two-fold or greater increase in the disengaging time would serve as a 
warning that flooding trouble might occur in a plant contactor at the same solvent dose.

Special Tests

There are a number of other solvent properties we may look at from time to time as a function of cumulative absorbed dose. These might include interfacial tension, wetting characteristics (contact angle on stainless stee1), standard $\mathrm{U}, \mathrm{Pu}$, and fission product distribution ratio tests, controlled dispersion-disengaging time tests, etc. Again, these would be supplied for the record together, where possible, with some indication of normal values obtained at the Hanford Purex Plant and the corresponding plant performance. 


\section{REFERENCES}

1. C. A. Blake, Jr. "Solvent Stability in Nuclear Fuel Processing: Evaluation of the Literature, Calculations of Radiation Dose, and Effects of Iodine and Plutonium," ORNL-4212, March 1968.

2. L. L. Burger and E. C. MCClanahan. "Gamma Radiolysis--Tributy1. Phosphate and Its Diluent System," Ind. Eng. Chem., Vol. 50, No. 2, February 1958, pp. 153-156.

3. M. A. Wade and S. S. Yamamura. "Determination of Dibutylphosphate in Tributy.lphosphate-Kerosene Solutions--An Alumina-Column Separation Procedure," TID-7655, October 11, 1962.

4. A. H. Kibbey and W. Davis, Jr. "Methylation and Gas Chromatographic Analysis of the Decomposition Products of Tributyl Phosphate," ORNL-TM-2289, August 1, 1968.

5. A. S. Jennings. "A Miniature Centrifugal Contactor," DP-680, March 1962.

6. C. S. Schlea, H. E. Henry, M. R. Caverly, W. J. Jenkins. "Purex Process Performance with Short-Residence Contactors," DP-809, September 1963.

7. D. A. Orth and J. M. McKibben. "Evaluation of Centrifugal Contactors," DPSPU .69-30-1, June 1969.

8. W. E. Unger, et a1. "Aqueous Processing of LMFBR Fuels, Progress Report, March 1969, No. 1," ORNL-TM-2552, Apri1 1969.

9. E. L. Nicholson. "Preliminary Investigation of Processing Fast-Reactor Fuel in Existing Plant," ORNL-TM-1784, May 1967.

10. W. E. Unger, et al. "LMFBR Fuel Cycle Studies, Progress Report for October, No. 8," ORNL-TM-2764, November 1969.

11. L. V. Spencer. "Energy Dissipation by Fast Electrons," National Bureau of Standards, Monograph No. 1, September 10, 1959.

12. L. Stieglitz, W. Ochsenfeld, H. Schmieder. "The Influence of the Radiolysis of Tributyl Phosphate on the Plutonium Yield in the Purex Process for High Plutonium Content," EURFNR-663 (translated from KFK-691, November 1968).

13. Anon. "Analytical Method for the Determination of Dibutyl Phosphoric Acid in Tributyl Phosphate Kerosene Mixtures (Infra-Red Spectrometry)," $P G-402$, UKAEA, Windscale, 1962.

14. P. G. M. Brown, et al. "The Significance of Certain Complexes of Ruthenium, Niobium, Zirconium, and Uranium in Plant Processes," Progress In Nuclear Energy, Series III. Prócess Chemistry, Vo 1. 3, Pergamon Press, N.Y., T961. 
15. A. Duncan, A. Naylor, and B. F. Warner. "Fission Product Behavior in the First Contactor of a TBP Process," Solyent Extraction Chemistry of Metals, p. 3, Macmillan, London (1965).

16. G. L. Richardson, et a. . "Hot Semiworks Strontium-90 Recovery Program," HW-72666, July 17, 1963.

17. C. J. Hardy and D. Scargi11. "Studies on Mono- and Di-n-butylphosphoric Acids-III. The Extraction of Zirconium from Nitrate Solution by Di-n-butylphosphoric Acid," J. Inorg. Nucl. Chem.; 17, pp. 337-349 (1961).

18. W. W. Morgan, W. G. Mathers, and R. G. Hart. "Processing of Irradiated Reactor Fuels: Effect of ..Dibuty... Phosphate in the Tributyl Phosphate Processing System," Ind. Eng. Chem.; 51, p. 817 (1959).

19. H. T. Hahn and E. M. Vanderla11. "Complex Formation in the Dilute Uranyl Nitrate-Nitric.Acid-Dibuty. .Phosphoric Acid-Tributyl PhosphateAms co System," J. Inorg." Nuc]. Chem., 26, p. 191 (1964).

20. L. L. Burger. "Partition of Dibutyl Phosphate," HW-33682, November 8, 1954.

21. T. Rigg and W. Wild. "Radiation Effects in Solvent Extraction Processes," Progress in Nuclear Energy, Series III: Process Chemistry, Vol. 2, pp. 320-331, Pergamon Press, N.Y. (1958).

22. Perry's Chemical Engineers Handbook, 4th Edition, pp. 21-34, McGraw-Hill Book Co.; N. Y. (1963).

23. R. M. Wagner, E. M. Kinderman, and L. H. Towle. "Radiation Stability of Organophosphorus Compounds," Ind. Eng. Chem., 51, p. 45 (1959).

24. W. S. Groenier. "Some Factors Affecting the Choice of a Solvent Extraction Contactor for the 1st Cycle Reprocessing of LMFBR Fuels," ORNL-TM-2290, September 1968.

25. Chemical Processing Department Analytical Technical Manual, ed. by R. A. Schneider and K. M. Harman, HW-53368, 1961.

26. Selected Measurement Methods for Plutonium and Uranium in the Nuclear Fuel Cycle, ed. by R. J. Jones, TID-7029, 1961.

27. W. W. Schulz. Atlantic Richfield Hanford Co., informal communication, June 1970.

28. W. V. Mayneord. "Energy Absorption IV. The Mathematical Theory of Integral Dose in Radium Therapy," Brit. J. of Radiology, 18, p. 12 (1945).

29. H. M. Parker. "A Dosage System for Interstitial Radium Therapy. Part IIPhysical Aspects," Brit. J. Of Radiology, 11, p. 313 (1938). 
I. Derivation of Equations - J. D. Kaser

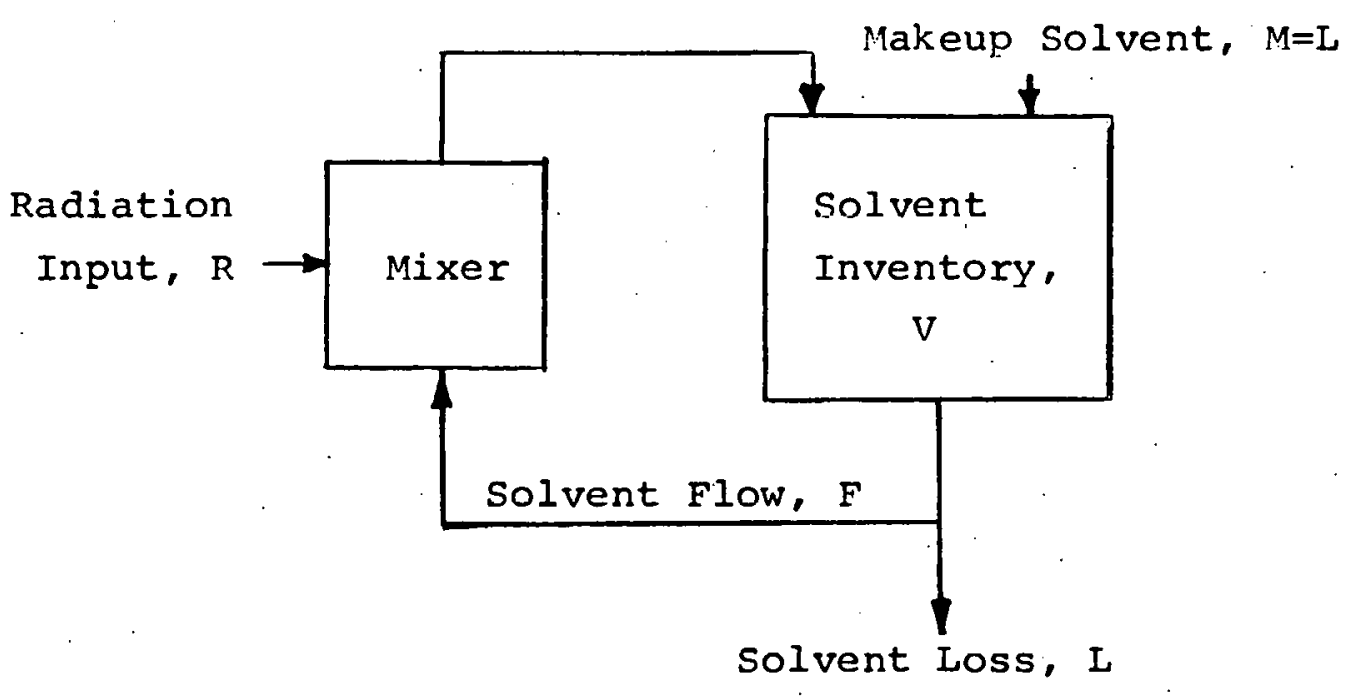

NOMENCLATURE

$C=$ Cumulative absorbed dose, W-hr/liter.

$D_{e}=$ Effective power density in aqueous feed, watt/liter.

$E=$ Solvent dose/pass $=t_{m} \mathrm{D}^{\mathrm{P}}, \mathrm{W}$-hr/liter.

$F=$ Solvent flow rate, liters/hr.

$\mathrm{L}=$ Solvent loss rate, liters $/ \mathrm{hr}=$ makeup solvent rate .

$\mathrm{n}=$ Number of solvent makeup batches added.

$\mathrm{P}=$ Aqueous feed volume fraction in mixer.

$\mathrm{R}$ = Radiation dose rate, watts.

$t=$ Time, hours

$t_{m}=$ Organic residence time in mixer, hours. -

$V=$ Total solvent volume in system, liters.

$v_{0}=$ Initial solvent volume in system, liters. 
$\mathbf{x}=$ Fraction of initial solvent remaining just before solvent makeup batch is added $\mathrm{V} / \mathrm{V}_{0}=\left(\mathrm{V}_{0}-\mathrm{L} \theta\right) / \mathrm{V}_{0}$

$\theta=$ Time between solvent makeup batch additions.

Case 1: Makeup solvent is added continuously to keep the solvent inventory $\underline{\mathrm{V}}$ constant.

The absorbed energy balance is given by

$$
\mathrm{V} \frac{\mathrm{dC}}{\mathrm{dt}}=\mathrm{R}-\mathrm{CL} \text {. }
$$

At time $\underline{t}$, the cumulative absorbed energy is given by

$$
C=\frac{R}{L}\left(1-e^{-L t / V}\right) \text {. }
$$

The solvent dose/pass, $\underline{E}$, is related to $\underline{R}$ by

$$
E=\frac{R}{F^{\prime}}
$$

therefore, $c=\frac{E F}{\mathrm{~L}}\left(1-\mathrm{e}^{-\mathrm{Lt} / \mathrm{V}}\right)$.

Where $L t / V$ is small (i.e., very low solvent loss or short irradiation time), Equation (5) reduces to

$$
\mathrm{C}=\frac{\mathrm{EFt}}{\mathrm{V}}=\frac{\mathrm{Rt}}{\mathrm{V}}
$$


Case 2: Makeup solvent is added batchwise at regular. intervals to restore orlainal solvent volume.

The absorbed radiation balance for this case is given by

$$
\left(V_{O}-L t\right) \frac{d C}{d t}=R
$$

Thus at time $\underline{\theta}$, just before makeup solvent is added. for the first time,

$$
c_{1}=\frac{R}{L} \ln \left(\frac{v_{0}}{v_{0}-L \theta}\right)+c_{0} \text {. }
$$

The absorbed dose just after the first batch of makeup solvent is added is

$$
c_{I}^{\prime}=\left[\frac{R}{L} \ln \left(\frac{V_{0}}{V_{0}-L \theta}\right)+c_{0}\right]\left(\frac{V_{0}-L \theta}{V_{0}}\right) \text {. }
$$

Substituting $x$ for $\frac{V_{0}-L \theta}{V_{0}}, E F$ for $R$, and letting $c_{0}=0$,

$$
c_{1}=\frac{E F}{L} \ln \frac{1}{x}
$$

and $C_{1}^{\prime}=\frac{x E F}{L} \ln \frac{1}{x}$.

continuing, just before the second makeup batch,

$$
c_{2}=(1+x) \frac{E F}{L} \ln \frac{1}{x}
$$


and just after the second batch,

$$
c_{2}^{\cdot}=\left(x+x^{2}\right) \frac{E F}{L} \ln \frac{1}{x}
$$

Likewise, just before the nth batch of makeup solvent

$$
c_{n}=\left(\frac{E F}{I} \ln \frac{1}{x}\right) \quad \sum_{1}^{n} x^{n-1}
$$

and just after the nth batch

$$
C_{n}^{\prime}=\left(\frac{E F}{L} \ln \frac{1}{x}\right) \quad \sum_{1}^{n} x^{n}=x C_{n}
$$

Since $x<1$ and $\sum x^{n}$ is a geometric progression,

$$
\sum_{1}^{n} x^{n}=x^{n}-1
$$

Thus,

$$
\begin{aligned}
& c_{n}=\left(\frac{x^{n}-1}{x-1}\right) \quad \frac{E F}{L} \ln \frac{1}{x} \text { and } \\
& c_{n}^{\prime}=x\left(\frac{x^{n}-1}{x-1}\right) \quad \frac{E F}{L} \ln \frac{1}{x} .
\end{aligned}
$$

At steady state, where $\mathrm{n} \rightarrow \infty$, the maximum absorbed dose just before solvent is added is '

$$
c_{\infty}=\left(\frac{1}{1-\bar{X}}\right) \frac{E F}{L} \ln \frac{1}{\bar{x}^{\prime}} \text { and }
$$




$$
C_{\infty}^{\prime}=\left(\frac{x}{1-x}\right) \frac{E F}{L} \ln \frac{I}{x}
$$

The degree of approach to the maximum study state absorbed dose is

$$
\frac{c_{n}}{c_{\infty}}=1-x^{n} .
$$

\section{Example Calculations}

A. The Hanford Purex Plant has a solvent inventory in the No. I system of about $25,000 \mathrm{gal}$. The solvent loss rate is about 0.168 of the lax solvent feed rate; and the loss is replaced when the inventory has decreased by about $25 \%$, or when $x=0.75$. The maximum or steady state absorbed dose is given by equation (19):

$$
\begin{aligned}
C_{\infty} & =\left(\frac{1}{1-0.75}\right)\left(\frac{E F}{0.0016 \mathrm{~F}}\right) \ln \frac{1}{0.75} \\
& =2500 \mathrm{E} \ln 1.33=720 \mathrm{E} .
\end{aligned}
$$

The number of batches of makeup solvent to reach 908 of the maximum dose is determined from Equation (21):

$$
\frac{c_{n}}{c_{\infty}}=0.9=1-0.75^{n}
$$


and $\mathrm{n}=\frac{\ln 0.1}{\ln 0.75}=8.0$ batches.

The Purex IA column has a cross sectional area of about $3.7 \mathrm{ft}^{2}$. At a "IAX volumetic rate of 1000 $\mathrm{gal} / \mathrm{hr}-\mathrm{ft}{ }^{2}$, the solvent rate is $3700 \mathrm{gal} / \mathrm{hr}$ and the loss rate is $5.9 \mathrm{gal} / \mathrm{hr}$. The time between batch solvent additions is equal to the time required to lose $25 z$ of the inventory:

$\theta=\frac{(0.25)(25,000)}{5.9}=1060 \mathrm{hrs}$, and the time to reach $90 \%$ of the steady-state dose is $(8)(1060)=8480$ hrs or 353 days.

B. The solvent irradiation test stand will have a minimum solvent inventory during recycle testing of about $225 \mathrm{ml}$. The assumed solvent loss rate (due to sampling mostly) will be about $0.5 \%$ of the solvent feed rate, and the loss will be replaced by $25 \mathrm{ml}$ additions of fresh solvent $\left(x=\frac{250-25}{250}=0.9\right)$. The cumulative solvent dose before makeup addition, from Equation (17), will be:

$$
\begin{aligned}
C_{n} & =\left(\frac{0.9^{n}-1}{0.9^{-1}}\right)\left(\frac{E F}{0.005 F}\right) \ln \frac{1}{0.9} \\
& =210.8 \text { E }\left(1-0.9^{n}\right) .
\end{aligned}
$$


But $\mathrm{n}=\mathrm{Lt} / \mathrm{L} \theta=t / \theta$, and $\theta=0.025 / \mathrm{L}=0.025 / 0.005 \mathrm{~F}$;

therefore, $\mathrm{n}=0.2 \mathrm{Ft}$.

Also, $\quad E=t_{m} e^{P}$,

where $\quad P=$ feed volume fraction in mixer;

$t_{m}=$ solvent residence time in mixer, hours.

After substitution of the relationships for $\underline{E}$ and $\underline{n}$,

$$
\frac{C_{n}}{D_{e}}=210.8 t_{m} P\left(1-0.9^{0.2} \mathrm{Ft}\right)=\frac{\text { cum. } W-h r / l \text { absorbed }}{\text { effective } W / \ell \text { in feed }} .
$$

The results of calculations for three laboratory mixer sizes are plotted in Figure A-1 for the case where the solvent and aqueous feed volumes in the mixer are equal. With this stipulation, $P=0.5$ and

$$
t_{m}=\frac{0.5 V_{m}}{F}
$$

where $\quad v_{m}=$ volume of laboratory mixer, liters.

Therefore,

$$
\frac{C_{n}}{D_{e}}=\frac{52.7 V_{m}}{F} \quad\left(1-0.9^{0.2 \cdot F t}\right)
$$




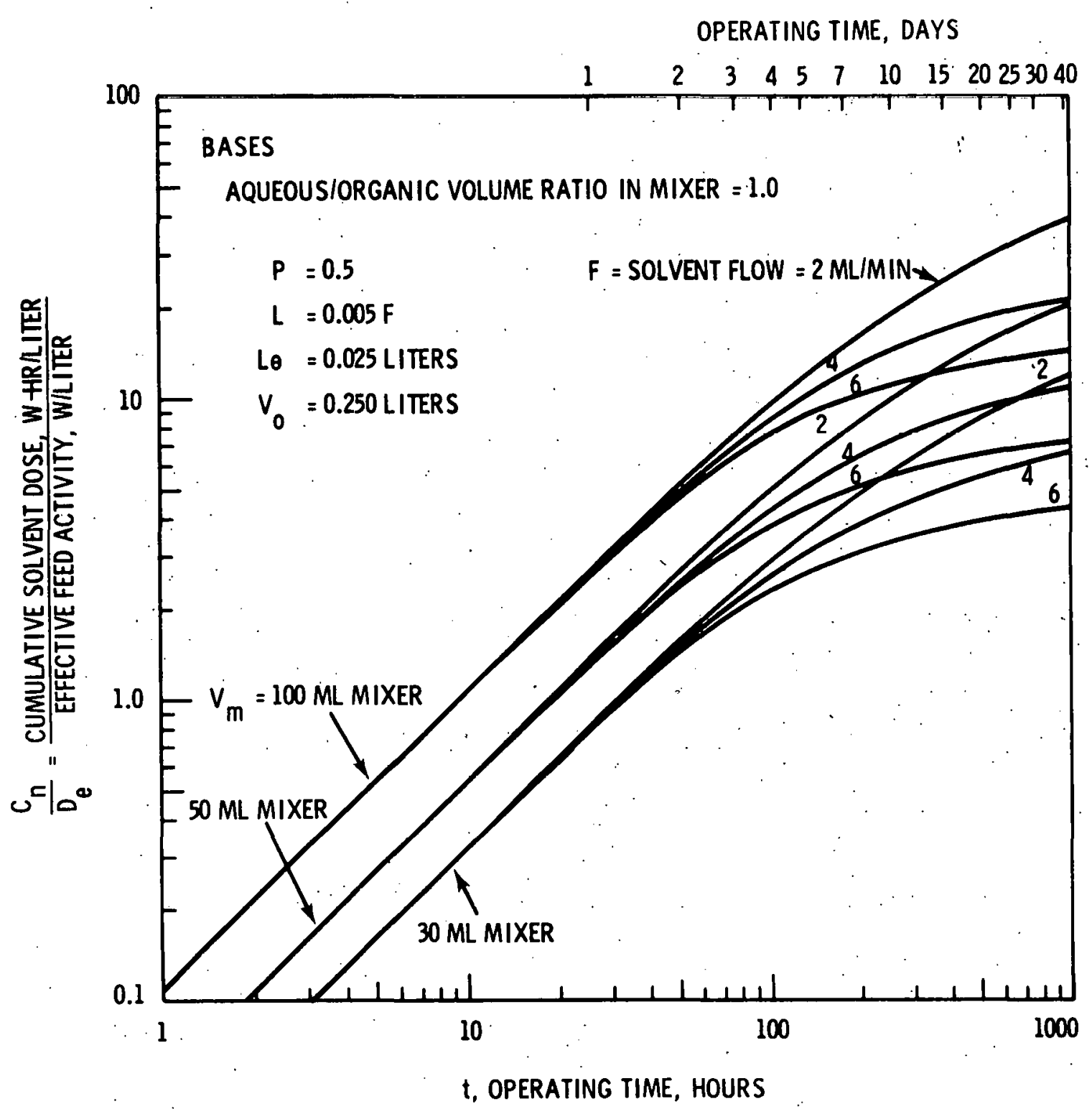

FIGURE A-1. CUMULATIVE ABSORBED RADIATION DOSE IN TEST-STAND SOLVENT 
APPENDIX B

\section{CALCULATION OF SINGLE-PASS SOLVENT DOSE}

\section{Pulse Column Solvent Residence Time}

Pulse columns are designed to operate at superficial volume velocities up to about $2000 \mathrm{gal} / \mathrm{hr}-\mathrm{ft}^{2}$. In the Hanford Purex process, the solvent flow is about $70 \%$ of the total flow rate, so a reasonable range of solvent flow rates would be 500 to $1500 \mathrm{gal} / \mathrm{hr}^{-\mathrm{ft}^{2}}$, which is equivalent to superficial linear velocities of 67 to $200 \mathrm{ft} / \mathrm{hr}$. The solvent occupies about 85 of the column volume in the contacting section (organic phase continuous, pulse frequency set to about $80-90 \%$ of the flooding frequency); therefore, the actual linear solvent velocity is 79 to $236 \mathrm{ft} / \mathrm{hr}$. The Hanford. Purex IA column has a 15-ft-tall extraction section and a 20-ft-tall scrub section; therefore the solvent residence times range from 4 to $11 \mathrm{~min}$. in the extraction section and 5 to $15 \mathrm{~min}$. in the scrub section. The calculations are summarized in Table B-1. 
TABLE B-1

Solvent Residence Times in the Purex lA column

Solvent Flow Rate

\begin{tabular}{l} 
Volume Velocity. \\
GPH/Ft \\
\hline
\end{tabular}

500

1000

1500

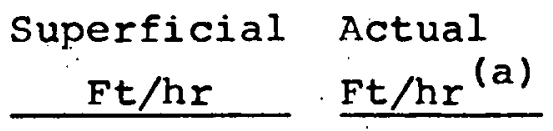

79

157

236

134

201
Solvent Residence Time ${ }^{(b)}$

Hours Minutes

Extr. Scrub Extr. Scrub

$\begin{array}{llllll}0.191 & 0.254 & 11.4 & 15.3\end{array}$

$0.095 \quad 0.127$

5.7

7.6

3.8

5.1

(a) Solvent assumed to occupy $85 \%$ of column volume.

(b) Extraction section height $=15 \mathrm{ft}$; scrub height $=20 \mathrm{ft}$. 
II. Solvent Dose Per Pass in Pulse Columns

The solvent dose in the extraction section of a lA column can be approximated by the previously defined equation

$$
E=t_{m} D_{e^{p}}
$$

where $\mathrm{E}=$ absorbed radiation dose in solvent, $w-n r / 11$ ter.

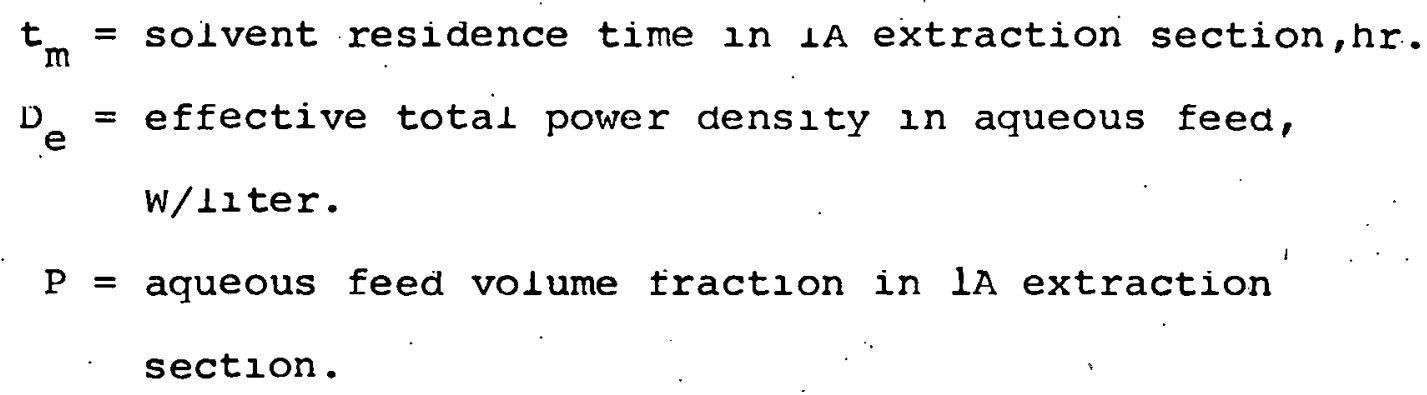

In the Hanford Purex process, the fraction of the feed activity in the aqueous phase throughout the extraction section $=\frac{\perp A F}{1 A W}=0.4$. The overall fraction of the extraction section occupied by the aqueous phase is 0.15. 'l'herefore,

$$
P=(0.15)(0.4)=0.06
$$

Similarly, for the ORNL.LMFBR flowsheet,

$$
P=(0.13)(0.75)=0.1125 \text {. }
$$

Single-pass and cumulative solvent doses were calculatcd for both Purex and LMFBR tloweneets as a function of feed activity and solvent flow rate. The results are presented in Table $B-2$. No corrections were applied for solvent irradiation in the disengaging section (calculated to be about $20 \%$ of that in the extraction section by Groenier( ${ }^{(8)}$ ). 
Calculated Absorbed Solvent Radiation Dose in a lA Column

Solvent Volume

Velocity

$\alpha$

GPH $/$ Ft. $^{2}$

500

1000

1500
E, Solvent Dose Per Pass, $W$-hr/liter

$\frac{\text { Purex }^{(b)}}{\underline{D_{e}=0.5 \mathrm{~W} / \ell} \cdot \underline{1 \mathrm{~W} / \ell} \cdot \frac{5 \mathrm{~W} / \ell}{10 \mathrm{~W} / \ell}}$

0.0057

0.0115

0.107

0.215

0.0028

0.0057

0.054

0.107

0.0019

0.0038

0.036

0.072

C, Cumulative Dose at Steady-state, $w-h r / \ell(a)$

500

1000

1500
4.1

8.3

2.0

1.4
4.1

2.7

155

77

39

77

26

52

(a) Cumulative dose $=720 \mathrm{E}$ (See Appendix A example calculation)

(b) Aqueous feed volume fraction $=0.06$

(c) Aqueous feed volume fraction $=0.1125$. 


\section{Test-Stand Mixer Sizing Calculations}

The test-stand mixers were sized to provide solvent residence times comparable to those obtained in the extraction section of a typical lA pulse column, or about 4 to 12 minutes. A further restraint, as discussed in the text, required that the solvent flow be set to provide solvent residence times in the scrub contactor comparable.. to those in a pulse column scrub section, or about 5 to 15 minutes as shown in Table B-l. The solvent holdup in the test-stand 1 A scrub section is about $26 \mathrm{ml}$; therefore solvent flow rates of 2,4 , and $6 \mathrm{ml} / \mathrm{min}$. will provide scrub residence times of $13,6.5$, and $4.3 \mathrm{~min}$, corresponding to solvent volume velocities of 590,1180 and $177-9 \mathrm{gal} / \mathrm{hr}^{-\mathrm{ft}^{2}}$ in the IA pulse column.

The mixer vessel could be sized and operated to match both the solvent residence time and $A / 0$ volume rates obtained in the IA extraction section. However, operation at aqueous/organic ratios differing significantly from ( 1.0 increases the percentage of error in dose rate calculations caused by small differences between actual and assumed values for $\mathrm{P}$ and $t_{m}$ in Equation (1). This is illustrated in Figure $B-1$ where the absorbed dose for a given feed activity is plotted versus the aqueous/organic flow ratios for three mixer sizes. The maxima in these curves corresponds to an aqueous feed volume fraction of $0.5(\mathrm{~A} / 0=1.0)$. 


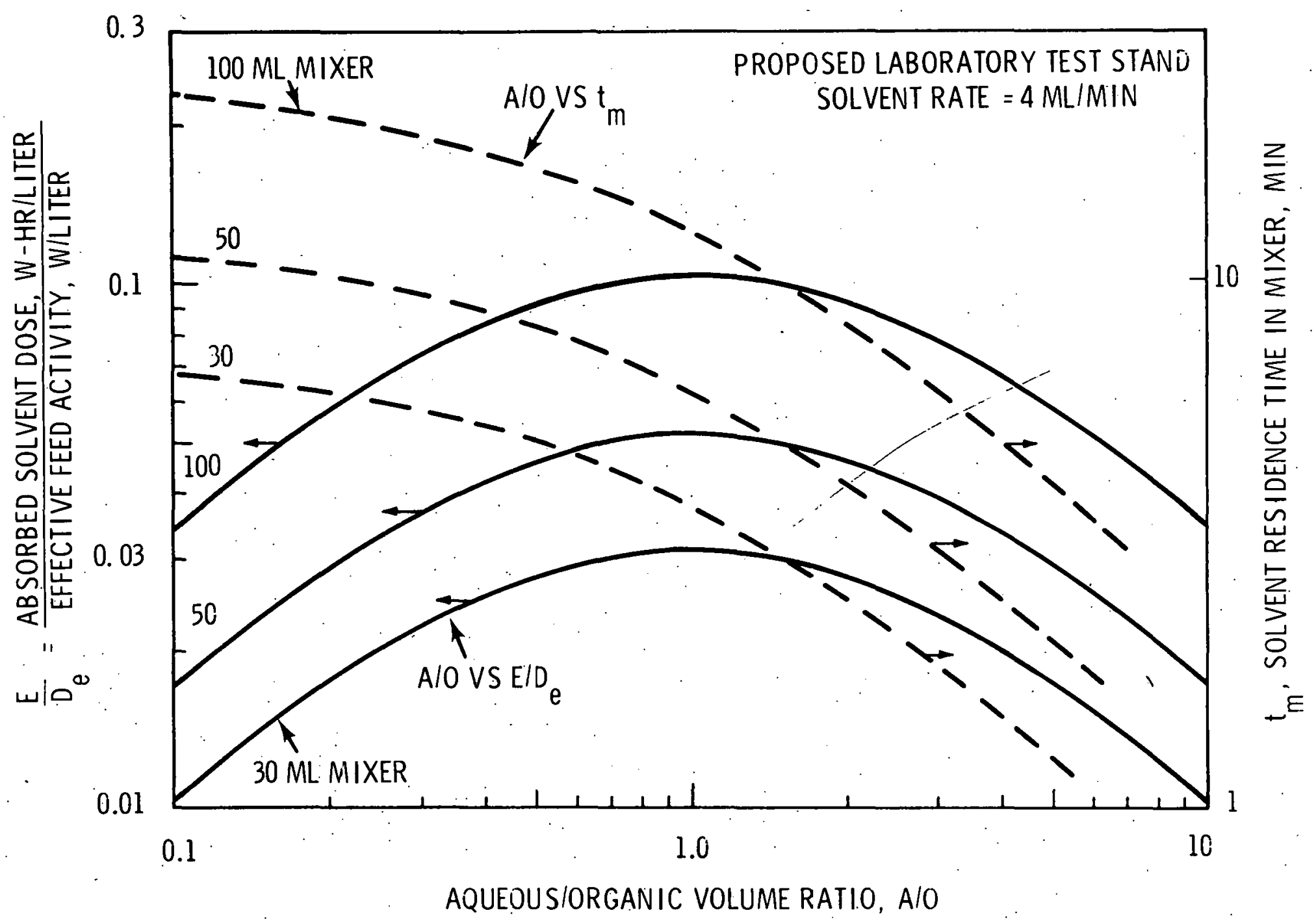

FIGURE B-1. EFFECT OF AQUEOUS/ORGANIC FLOW RATIO ON SINGLE-PASS SOLVENT RADIATION DOSE AND SOLVENT RESIDENCE TIME 
The data in Figure $\mathrm{B}-1$ for the 30,50 , and $100 \mathrm{ml}$ mixers were calculated from the previously defined equation:

$E=t_{m} D_{e} P$

Let $V_{m}=$ volume of mixer, liters

$\mathrm{V}_{\mathbf{s}}=$ volume occupied by solvent, liters

$\mathrm{V}_{\mathrm{a}}=$ volume occupied by aqueous feed, liters

$\mathrm{F}=$ solvent flow rate, liters/hr.

$t_{m}=$ solvent residence time in the mixer, hours.

$P=\frac{V a}{V_{m}}=$ aqueous feed fraction in mixer.

$\mathrm{v}_{\mathrm{s}}=\mathrm{v}_{\mathrm{m}}-\mathrm{v}_{\mathrm{a}}=\mathrm{v}_{\mathrm{m}}(1-\mathrm{P})$

$t_{m}=\frac{V s}{t}=\frac{V m(1-P)}{F}$

$P=\frac{v_{a}}{V_{a}+V_{s}}=\frac{V_{a} / V_{s}}{1+V_{a} / V_{s}}=\frac{A / O}{1+A / 0}$

After substitution,

$\frac{E}{D_{e}}=\frac{V m(A / O)}{F(1+A / O)^{2}}=\frac{\text { absorbed solvent dose, } \text { w-hr/liter }}{\text { Feed activity, watts/liter }}$.

and $t_{m}=\frac{V_{m}}{F(1+A / O)}$ 
If we fix $P$ at $0.5(\Lambda / O=1)$,

$$
\frac{E}{D_{e}}=\frac{0.25^{V / m}}{F}
$$

which represents the maximum dose attainable in a given mixer. 
APPENDIX C

ESTIMATION OF BETA AND GAMMA ENERGY ABSORPTION IN IRRADIATION VESSELS

J. C. Sheppard and G. L. Richardson

Betà Energy Absorption

An estimated 85 to $90 \%$ of the beta energy in the feed to our irradiation contactors will be absorbed by the two phases. The energy deposition will be distributed between the two phases in proportion to their volume ratio in the contactor with the intimate dispersion we obtain. These conclusions are based on the following analysis:

(1) Since the average atomic number of both the organic and the aqueous phase is about three (approximately equal electron densities); the stopping power of each phase should be similar. Thus, the two phases will look the same to CePr-144 beta particles passing through them.

(2) The average energy of CePr-144 beta particles will be about $1.0 \mathrm{MeV}$. The range of a beta particle in either phase will be the same, about $4 \mathrm{~mm}$. If the average diameter of a solvent drop is $0.6 \mathrm{~mm}$ or less, as measured, statistically the beta will pass through about six drops as it loses its energy. Furthermure, lile isutropic emission of the betas, the random motion of drops, and the uniform distribution of the beta emitters in the aqueous phase also contribute a uniform distribution of beta energy between the two phases.

(3) A beta particle can escape from the surface of an object only if the emitting nucleus lies within the range $R$ of the surface, and only one half of those emitted at the surface will escape absorption. 0f the betas emitted at an intermediate distance $X$ from the surface, the fraction that escapes absorption is

$$
F=\frac{2 \pi R(R-X)}{4 \pi R^{2}}=\frac{R-X}{2 R} .
$$


This represents the fractional area of a sphere of radius $R$ subtended by a plane (the surface of the object) passing through the sphere at a distance $R-X$ from the center. The average overall. value of $F$ as $X$ varies from 0 to $R$ gives the fraction of the betas emitted in, this volume element which are not absorbed:

$$
F=\frac{1}{R} \int_{0}^{R} \frac{R-X}{2 R} d X=\frac{1}{4}
$$

Therefore, $3 / 4$ of the betas emitted in this volume element will be absorbed.

Now consider a spherical object having a radius $\rho$ which is greater than the range of beta particles, $R$. This sphere can be divided into an. inner core with radius $(\rho-R)$ in which all the betas are absorbed and an outer annular sphere in which only $3 / 4$ of the betas are absorbed, as in the analysis above. The fraction of all the betas emitted which are absorbed is given by

$$
\begin{aligned}
F_{\text {abs }} & =F_{\text {inner }}+F_{\text {outer }} \\
& =\frac{(4 \pi / 3)(\rho-R)^{3}}{(4 \pi / 3) \rho^{3}}+3 / 4 \cdot \frac{(4 \pi / 3) \rho^{3}-(4 \pi / 3)(\rho-R)^{3}}{(4 \pi / 3) \rho^{3}} \\
& =3 / 4+(1 / 4)\left(\frac{\rho-R}{\rho}\right)^{3}
\end{aligned}
$$

When $\rho \gg R$, all of the beta energy is absorbed in the spherical object; when $\rho=R$, three-fourths of the energy will be absorbed. The table below shows the effect of various $R / \rho$ ratios on the fractional beta absorption. 


\begin{tabular}{ll}
$R / \rho$ & $\frac{F_{\text {abs }}}{0}$ \\
\hline 0 & 1.00 \\
0.01 & 0.99 \\
0.03 & 0.978 \\
0.05 & 0.964 \\
0.10 & 0.932 \\
0.15 & 0.914 \\
0.20 & 0.878 \\
0.25 & 0.829 \\
0.50 & 0.781
\end{tabular}

A similar analysis can be made for other geometrical shapes. For example, the beta absorption in cylindrical vessels such as our irradiation contactors is given by

$$
F_{\text {abs }}=3 / 4+(1 / 4)\left(\frac{D-2 R}{D}\right)^{2} \cdot\left(\frac{h-2 R}{h}\right)
$$

where $D$ is the internal diameter of the vessel and $h$ is the height of the solution in the vessel. For our small scale CePr-144 dosimetry experiments, the calculated value of $F_{a b s}$ is 0.85 for the $30 \mathrm{ml}$ vessel, 0.88 for the $50 \mathrm{ml}$ vessel, and 0.90 for the $100 \mathrm{ml}$ vessel. Radioisotopes with lower energies will, of course, be absorbed more efficiently. Gamma Energy Absorption

For our dosimetry tests, the gamma power density will be only about $1 \%$ of the beta power density and its fractional absorption can be ignored. For higher gamma/beta ratios and a spherical geometry, the fraction of the gamma energy escaping, $q_{s}$, can be approximated by

$$
q_{s}=\frac{1}{R} \int_{0}^{R} e^{-\mu R} d R=\frac{\mu}{\mu R}\left(1-e^{-\mu R}\right) \text {, }
$$

where $\mu$ - the linear absorption cuefricienl for the system, and 
$\mathrm{R}=$ the radius of the sphere.

This equation is commonily used to correct for self absorption of gammas in spherical sources:

Mayneord ${ }^{(28)}$ has calculated the escape probability or fraction of the gammas escaping, $q_{C}$, from an infinitely long cylinder of radius $R$ from the equation

$$
q_{c}=\int_{0}^{1} e^{-\mu R / \sqrt{1-x^{2}}} d x .
$$

This equation has not been reduced to a readily integrable form, but a table of $q_{c}$ values as a function of $\mu R$ is provided in the reference.

Values of $\mu$ to use in these equations were estimated from the average mass abśorption coefficients for our system. These were calculated for several gamma-energies from the equation

$$
\mu / \rho=\sum_{i} w_{i}\left(\mu_{i} / \rho_{i}\right)
$$

where $w_{i}=$ the weight fraction and $\mu_{i} / \rho_{j}=$ the mass absorption coefficient of the $i$-th element. The composition of the system to be irradiated was assumed to be an average of typical equilibrium aqueous and organic phase compositions present in the contactor at an organic/aqueous volume ratio of 1 . Carbon, nitrogen, oxygen, and phosphorous have approximately equal mass absorption coefficients, so these elements were all taken as oxygen. Uranium, hydrogen and "oxygen" will have average weight fractions of $0.0365,0.111$, and 0.867 , respectively; thus the equation for the mass absorption coefficient of the mixture is

$$
(\mu / \rho)_{\text {mixture }}=0.0365(\mu / \rho)_{U}+0.111(\mu / \rho)_{H}+0.867(\mu / \rho)_{0} .
$$


Since the density, $\rho$, of the mixture is nearly one, the mass absorption coefficient for the mixture is also approximately equal to the linear absorption coefficient, $\mu$. The table below lists the mass absorption coefficients for the elements and mixture for gamma energies of $0.2,0.5$, and $1.0 \mathrm{MeV}$ :

\begin{tabular}{|c|c|c|c|}
\hline & $\begin{array}{r}\text { Mass } \\
0.2 \mathrm{MeV} \\
\end{array}$ & $\begin{array}{l}\text { ion Coeff } \\
0.5 \mathrm{MeV} \\
\end{array}$ & $\begin{array}{l}\mathrm{\mu} / \mathrm{\rho} \\
1.0 \mathrm{MeV} \\
\end{array}$ \\
\hline Uranium & 1.15 & 0.140 & 0.0479 \\
\hline Hydrogen & 0.0525 & 0.0590 & 0.0555 \\
\hline Oxygen & 0.0268 & 0.0298 & 0.0280 \\
\hline Mixture & 0.0710 & 0.0375 & 0.0322 \\
\hline
\end{tabular}

The following table lists values of gamma energy escaping factors, $q_{s}$ and $q_{c}$, for several radi $i$, using the average mass absorption coefficients tabulated above for our experimental system as $\mu$.

Energy Escaping Factors for Spheres and Infinitely Long Cylinders

\begin{tabular}{|c|c|c|c|c|c|c|}
\hline \multirow[b]{2}{*}{ Radius, $\mathrm{cm}$} & \multicolumn{2}{|c|}{$0.2 \mathrm{MeV}$} & \multicolumn{2}{|c|}{$0.5 \mathrm{MeV}$} & \multicolumn{2}{|c|}{$1.0 \mathrm{MeV}$} \\
\hline & $q_{s}$ & $q_{c}$ & $q_{s}$ & ${ }^{q_{C}}$ & $q_{s}$ & ${ }^{q_{c}}$ \\
\hline 1 & 0.965 & 0.881 & 0.981 & 0.920 & 0.984 & 0.926 \\
\hline 2 & 0.932 & 0.805 & 0.963 & 0.875 & 0.968 & 0.887 \\
\hline 3 & 0.901 & 0.743 & 0.946 & 0.832 & 0.953 & 0.851 \\
\hline 4 & 0.871 & 0.657 & 0.928 & 0.743 & 0.938 & 0.815 \\
\hline 5 & 0.842 & 0.612 & 0.912 & 0.755 & 0.923 & 0.782 \\
\hline 10 & 0.716 & 0.391 & 0.834 & 0.595 & 0.855 & 0.639 \\
\hline
\end{tabular}

The radiolysis vessels used in our experiments will approximate cylinders having height-to-diamleter ratios between one and two. Parker ${ }^{(29)}$ has shown. that the absorbed radiation doses for cylinders with height-to-diameter ratios of one and two were only 1.5 and $4.5 \%$ greater, respectively, than for spheres of the same volume. Thus, the tabulated figures for $q_{s}$ should closely correspond to the energy escaping factors from our irradiation 
contactors. The radii of the radiolysis yessels will range between one and three centimeters. For typical gamma energies between 0.5 and $1 \mathrm{MeV}$, two to five percent of the gamma energy will be absorbed in the vessels. For all practical purposes, the contribution of gamma energy to the total solvent dose can be neglected.

The values of $q_{c}$ cannot be applied to our radiolysis vessels, but they can be used to estimate the gamma energy absorbed in pulse columns. Thus, about $40 \%$ of the gamma energy in a typical. LMFBR dissolver solution would be absorbed in a $20-\mathrm{cm}$ diameter column. 


\section{APPENDIX D}

URANIUM, PLUTONIUM AND FISSION PRODUCT ANAL YTICAL METHODS

Uranium, plutonium, and fission products will be analyzed by standard analytical methods in use many years at Hanford. Most of these are described in References 25 and 26. A brief description of some of the methods we will use is given below:

URANIUM METHODS

1) Coulometric Method

Coulometric methods are based on the exact measurement of the quantity of electricity passed through a solution during the occurrence of a reaction involving the substance being determined. The quantity of reactant is computed directly from Faraday's law. The prime requisite is that only a single reaction take place, and conditions must be derived so that the current efficiency is 100 percent.

For uranium analyses, $U^{6+}$ is titrated to $U^{4+}$ according to the following reaction:

$$
u^{6+}+2 e^{-} \rightarrow u^{4+}
$$

General Information

Sample size: $\quad 0.2$ to $10 \mathrm{mg} \mathrm{U}$

Sample volume: $10 \lambda$ to $1500 \lambda$, depending on acidity

Sample. size required for 5\% accuracy: $200 \mu \mathrm{g}$

Sample size required for $1 \%$ accuracy: $1 \mathrm{mg}$

\section{2) X-Ray Fluorescence Method}

When an electron is ejected from the $K$ or $L$ shell of an element by an X-ray photon, electrons from outer orbits of the electron may return to the vacant orbit and characteristic $X$ rays will be produced. 
These $X$ rays are called fluorescent radiation. The fluorescent $X$ rays are in all respects like the characteristic $X$ rays of that element except in the manner of excitation. The emitted radiation passes through a collimating slit onto the crystal spectrometer and then into a detector (usually a Geiger-Müller, proportional, or scintillation counter).

In quantitative applications the intensity from a given element is affected mainly by the amount of that element present (and in an almost linear manner). Consequently, standards need not be especially close to the unknown in composition.

General Information

Concentration range: $0.1 \mathrm{~g} / \mathrm{\ell}$ to $25 \mathrm{~g} / \mathrm{l}$

Sample acidity: mix standards in same range

Sample volume: $\quad 1 \mathrm{ml}$

Precision: $\quad \pm 2 \%$ if sample is in a consistent matrix

Sample concentration required for $5 \%$ accuracy: ${ }^{*} \quad 0.1 \mathrm{~g} / \mathrm{l}$

Sample concentration required for $2 \%$ accuracy: $0.2 \mathrm{~g} / \mathrm{l}$

Sample concentration required for $1 / 2 \%$ accuracy: $10 \mathrm{~g} / \mathrm{l}$

If an internal standard is used.

3) Fluorimetry Method

Many compounds will emi.t radiant energy after they have first absorbed radiant energy of some particular frequency. If there is no measurable time delay, usually less than $10^{-9}$ second, between the absorption and re-emission of the energy, the effect is call fluorescence. Measurement of the intensity of fluorescence is a convenient and rapid method for the determination of a large number of specific substances.

Uranium compounds fluoresce with a brilliant yellow color, and uranium is often determined by measuring the fluorescence of a sodium 
fluoride bead containing the uranium sample. The fluorescence of uranium fluoride is measured in a sodium fluoride matrix.

General Information

Concentration range: $0.001 \mathrm{~g} / \mathrm{l}$ to $25 \mathrm{~g} / \mathrm{l}$

Sample acidity: $\quad$ iTM $\mathrm{HNO}_{3}$

Sample volume: depends on concentration

Precision: $\pm 20 \%$ over the full range of concentration *

* The precision of a given determination can be increased by increasing the number of replicate measurements:

$$
\sigma_{\text {avg }}=\sqrt{\sigma^{2} / n}
$$

where $\sigma=$ analytical relative random error and $n=$ number of replicate measurements.

PLUTONIUM METHODS

\section{1) Alpha Counting Methods}

The number of alpha particles emitted by a given plutonium nuclide in a given period of time is directly proportional to the amount of that nuclide present. The weight of nuclide on the counting disc is determined by a proportionality factor, which is a function of two variables: the specific activity of the alpha emitter and the counting efficiency of the counting instrument. Normaliy a mixture of plutonium nuclides is present, and an experimental specific activity factor must be determined by an independent analytical method such as mass spectrometry or X-ray fluorescence. The analytical precision is affected by solids absorption, backscattering, coincidence counting loss, beta discrimination, and counting efficiency. The first two of these can be controlled in many instances by extracting the plutonium away from high salt of highly radioactive solutions with specific solvents such as hexone or TTA. 


\section{General Information}

Sample size: $100-10,000 \mathrm{~d} / \mathrm{m}$

Precision: $\quad \pm 5 \%$ for organic samples, $\pm 3 \%$ for aqueous samples

2) X-Ray Fluorescence Method

See discussion under uranium methods.

\section{FISSION PRODUCT METHODS}

Most fission products will be analyzed by radiochemical methods. A brief description of the methods and estimated precision is presented below.

1) Ganma Emitters: Radionuclides for which gamma ray emission is a significant factor in radioactive decay are determined by counting a sample aliquot on a high resolution gamma spectrometer using a Ge(L:i) detector! Radionuclides determined include: Nb-95, Zr-95, Cs-137, Cs-134, RuRh-106, Ru-103, Ce-141, and CePr-144. The accuracy and precision of reported concentrations depend on the relative concentrations present. Major constituents are determined to an accuracy of about $\pm 5 \%$. The uncertainty in the determination of minor constituents may be as high as $\pm 50 \%$.

We expect to obtain the following precision for the major radionuclides in our fuels:

\begin{tabular}{|c|c|c|}
\hline Radionuclide & $\begin{array}{c}\text { CePr-144/Radionuclide } \\
\text { Curie Ratio }\end{array}$ & $\begin{array}{l}\text { Estimated } \\
\text { Precision, } \% \\
\end{array}$ \\
\hline CePr-144 & 1 & \pm 2 (feed) \\
\hline \multirow[t]{2}{*}{ RuRh-106 } & $\leq 200$ & \pm 10 (feed) \\
\hline & $<1$ & \pm 3 \\
\hline \multirow[t]{2}{*}{$\mathrm{Nb}-95$} & $\leq 400$ & \pm 10 (feed) \\
\hline & $<1$ & \pm 5 \\
\hline \multirow[t]{2}{*}{ Zr-95. } & $\leq 800$ & \pm 20 (feed) \\
\hline & $<1$. & \pm 10 \\
\hline
\end{tabular}

* Detection 1 imit will be about $10^{-3} \mu \mathrm{Ci} / \mathrm{ml}$ at indicated precisions. Sample sizes will be $10^{-2}$ to $100 \mu \mathrm{Ci}$ ( $10 \mathrm{ml}$ maximum volume). 
2) Beta Emitters: "Total beta" activity is determined by counting a sample aliquot with a thin window, gas flow, proportional counter. A counting efficiency of $50 \%$ is used to convert counts per minute to disintegrations per minute. Although this counting efficiency is estimated to be close to the actual counting efficiency for the mixture of beta emitters present in normal high-level waste samples, a large uncertainty exists because of the possible variations in sample composition. This method, if used, will provide only a rough check of the total beta activity as determined by analysis of individual beta emitters. The accuracy is $\pm 25 \%$ with a precision of $\pm 5 \%$. The detection limit is $10^{-3} \mu \mathrm{Ci} / \mathrm{ml}$.

3) Strontium-90: Strontium-90 is determined by separating the total strontium by chromatographic elution from a cation exchange column and measuring the yttrium-90 buildup with a proportional beta counter. The estimated accuracy is $\pm 10 \%$ with a precision of $\pm 5 \%$. The detection limit is $10^{-3} \mu \mathrm{Ci} / \mathrm{ml}$.

4) Rare Earths (Total): The total rare earths are determined gravimetrically after precipitation as the oxalates and ignition to the oxide. If the rare earths present are known to consist primarily of cerium, results are calculated assuming the dioxide is formed. If cerium is not the primary constituent, the results are calculated assuming that sesquioxide is formed. Elements forming acid insoluble oxalates interfere. The estimated accuracy is $\pm 15 \%$, precision is $\pm 7 \%$, and the detection limit is $2000 \mathrm{ppm}$. 
OFFSITE

No. of

Copies

1

AEC, Argonne National Laboratory, 9700 S. Cass Avenue, Argonne, Illinois 60439

M. E. Jackson, RDT Senior Site Representative

AEC, Atomics International, P. 0. Box 1446, Canoga Park, California 91304

R. L. Morgan, RDT Senior Site Representative

1

AEC, Canoga Park Area Office, USAEC, P. 0. Box 591 , Canoga Park, California 91304

C. W. Richards

AEC Chicago Patent Group

G. H. Lee, Chief

AEC Division of Reactor Development and Technology

Asst Dir for Project Management

FFTF Project Office

Asst Dir for Plant Engineering

Asst Dir for Engineering Standards

Asst Dir for Reactor Engineering

Asst Dir for Nuclear Safety

LMFBR Program Manager, RDT:PM

W. G. Belter

J. Crawford

N. Haberman

P. A. Halpine

W. H. McVey

K. L. Mattern

W. A. Nelson

W. H. Regan

0 . T. Roth

H. Schneider

J. M. Simmons

E. E. Sinclair

A. N. Tardiff

C. E. Weber

M. J. Whitman

AEC Division of Technical Information Extension

AEC, Gulf Energy and Environmental Systems, Inc., P. 0. Box 2325, San Diego, California 92112

R. H. Ba11, RDT Senior Site Representative 
AEC, Idaho Operations Office, P. 0. Box 2108, Idaho Falls, Idaho 83401

K. K. Kennedy

AEC, Oak Ridge Nationàl Láboratory, RDT Site Office

D. F. Cópe, RDT Senior Site Representative

R. L. Philippone

AEC, Washington

P. R. Clark, Division of Naval Reactors

J. S. Griffo, Division of Space Nuclear Systems

W. R. Voight, Jr., Division of Production

Allied Chemical Corporation, Industrial Chemicals Div., P. 0. Box 405, Morristown, New Jersey 07960

A. Schneider

Allied Chemical Nuclear Products; Inc., P. 0. Box 35, Florham Park, New Jersey 07932

R. I. Newman

E. M. Shank

Argonne National Laboratory, 9700 South Cass Avenue, Argonne, Illinois 60439

A. Amorosi, LMFBR Program Office Leslie Burris, Jr., Associate Director of Chemical Engineering Division

S. Lawroski

W. J. Mecham

M. Nevitt, Director, Metallurgy Division

W. B. Seefeldt

C. E. Stevenson

R. C. Vogel

D. S. Webster

Argonne National Laboratory, East Area EBR-2, National Reactor Testing Station, Scoville, Idạho

Philip Fineman

ATCOR, Inc., 5 Westchester Plaza, Elmsford, New York 10523 Lois Seulowitz, Technical Librarian

Atomics International, Division of North American Rockwe11, Inc., P. 0. Box 309, Canoga Park, California 91304 Simcha Golan 
No. of

Copies

3

Babcock \& Wilcox, Research and Development Division, P. 0. Box 1260, Lynchburg, Virginia 24505
R. V. Carlson
E. M. Croft
E. W. Dewel1

1

Bechtel Corporation
J. J. Teachnor

Brookhaven Nationàl Laboratory, Upton, Long Is land, New York $\$ 1973$

W. E. Winsche

Combustion Engineering, Inc., Nuclear Division, P. 0. Box 500, Windsor, Connecticut 06095

\section{R. P. Varnes}

Dow Chemical Company, Rocky Flats Division, P. 0. Box 888, GoTden, Colorado 80401

D. L. Ziegler

E. I. du Pont de Nemours and Company, Savannah River Laboratory, Aiken, South Carolina 29801
H. J. Groh
C. H. Ice
L. H. Meyer
D. A. Orth
E. B. Sheldon

General Electric Company, 175 Curtner Avenue, San Jose, Calffornta 95125

R. G. Barnes

General Electric Company, 310 De Guigne Drive, Sunnyvale, California 94086

A. S. Gibson

General Electric Company, Vallecitos Nuclear Center, Vallecitos Road, Pleasanton, California 94566

W. H. Reas

General Electric Company, Knolls Atomic Power Laboratory, P. 0: Box 1072, Schenectady, New York 12301

R. A. Proebste] 
Gulf Energy and Environmentàl Systems; Inc., P. 0. Box 608, San Diego, California 92.112

Lionel Brooks

L. J. Colby, Jr.

R. H. Graham

Idaho Nuclear Corporation, P. 0. Box 1845, Idaho Falls, Idaho 83401

J. A. Buckham

W. J. Maeck

Liquid Metàl Engineering Center

R. W. Dickinson

Liquid Metal Information Center

A. E. Miller

Massachusetts Institute of Technology, Cambridge, Massachusetts 02139

Manson Benedict

Mound Laboratory, Building A, Room 155, Miamisburg, Ohio 45342

J. J. Goldin

S. Freeman

National Lead Company of Ohio, P. 0. Box 39158, Cincinnati, Ohio 45239

\section{S. Marshall}

National Lead Company, 111 Broadway, New York, New York 10006

S. H. Brown, Assistant to Manager

Núcleàr Fuel Services, Inc., Wheaton Plaza, Suite 906, Wheaton, Maryland 20902

W. H. Lewis, Vice President

2

Nuclear Materials and Equipment Corporation, Apollo, Pennsylvania 15613

M. Selman

S. H. Smi ley

R. E. Blanko

R. E. Brooksbank

D. J. Crouse 
No. of

Copies

(Oak Ridge Nationàl Laboratory)

W. W. Davis, Jr.

D. E: Ferguson

L. M. Ferris

J. H. Goode

D. E. Horner

A. R. Irvine

R. H. Rainey

W. E. Unger

V. C. A. Vaughen

C. D. Watson

M. E. Whatley

R. G. Wymer

United Nuclear Corporation, Grasslands Road, Elmsford, New York 10523

A. Strasser

Westinghouse Electric Corporation

D. C. Spencer

4

Westinghouse Electric Corporation, P. 0. Box 158, Madison, Pennsylvania 15663

E. F. Beckett

P. Murray

W. C. Ritz

J. D. Sutherland

1

Westinghouse Electric Corporation, Nuclear Fuels Division, P. 0. Box 355, Pittsburgh, Pennsyivania 15230

R. F. 01son.

ONSITE - HANFORD

No. òf

Copies.

AEC Chicago Patent. Office

R. K. Sharp (Richland)

5

USAEC, Richland, Wastington

0 . J. Elgert

P. G. Holsted

J. Morabito

J. M. Shivley

A. D. Toth 
DISTR-6

No. of

Copies

3

AEC RDT Assistant Director of Pacific Northwest Programs

T. A. Nemzek

4

Atlantic Richfield Hanford Company, P. 0. Box 250, Richland, Washington

G. L. Ritter

M. J. Szulinski

W. W. Schulz

R. E. Tomlinson

1

Atlantic Richfield Hanford Company, Nuclear Diversification Department, 1201 Jadwin Avenue, Richland, Washington

H. C. Rathvon

4

Battelle Northwest, P. 0. Box 999, Richland, Washington 99352

J. W. Bartlett

R. E. Burns

D. R. de Halas

H. H. Van Tuyl

1

Bechtel Corporation

W. A. Smith (Richland)

59

WADCO Corporation

G. J. Alkire

H. J. Anderson

J. M. Atwood (2)

J. G. Bradley

G. S. Cochrane

C. R. Cooley

W. H. Esselman

E. A. Evans

W. M. Gajewski

J. E. Hanson

E. N. Heck

J. N. Judy

H. T. Knight

F. J. Leitz

R. E. Lerch

J. M. Norris

D. G. Ott

G. L. Richardson (20)

W. F. Sheely

R. C. Smith

J. N. Strode

B. Wolfe

W. R. Wykoff

WADCO Document Control (15)

WADCO Tech. Pubs. 